\title{
1808 E SEUS IMPACTOS NO PROCESSO DE POLITIZAÇÃO DAS IDENTIDADES COLETIVAS: \\ MINAS GERAIS (1795-1831)
}

Ana Rosa Cloclet da Silva

Faculdade de História - Puc Campinas

\section{Resumo}

Este artigo analisa os possíveis impactos da transferência da Corte portuguesa para a América sobre o processo de construção e politização das identidades coletivas, na capitania de Minas Gerais. Argumenta-se que, inaugurando um período de inéditas transformações no mundo luso-brasileiro que atingiram diretamente a capitania mineira, 1808 criou condições concretas e simbólicas para a Independência, o que o torna marco privilegiado na compreensão das prioridades dos grupos locais em relação à construção do nacional, materializada nos projetos, expressões, comportamentos e identidades coletivas.

\section{Pallavras-Chaves}

Identidades $\bullet$ Minas Gerais $\bullet$ crise.

\section{Abstract}

This article analyzes the impacts of the Portuguese Court transference to America respect the identities construction and politization process, at Minas Gerais capitania. For this, support that 1808 had created concretes and symbolics conditions to Independence, which makes it a demarcation in the understanding about local political groups priorities concerning the national construction, reflected in the projects, behaviors and collectives identities.

\section{Keywords}

Identities $\bullet$ Minas Gerais $\bullet$ crisis 
E do convívio e das inter-relações desse caos foi emergindo, no cotidiano, essa categoria de 'colonos' que, depois, foi se descobrindo como 'brasileiros'. (Fernando A. Novais)

As contribuições apresentadas no presente texto são resultado de uma opção temática privilegiada na apreensão daquilo que é, necessariamente, instável durante um período de crise: o processo de construção das "identidades políticas coletivas". . No cerne de suas preocupações, situa-se o interesse em testar a hipótese $^{2}$ segundo a qual, no contexto da crise geral do Antigo Regime, os projetos elaborados nos planos local e regional, referidos a alguma realidade concreta da América portuguesa, esboçaram "potencialidades de tipo nacional", o que acarreta implicações decisivas tanto para o estudo das identidades coletivas, quanto daquilo que elas revelam sobre o processo do qual resultaria, em meados do XIX, um Estado e uma Nação brasileiros dotados de formato definido.

Para tanto, adota-se como recorte espacial a capitania e depois província de Minas Gerais, entre 1795-1831, buscando compreender a articulação desta porção americana da Monarquia portuguesa na ruptura do sistema luso-brasileiro e posterior formação do Estado nacional, bem como evitando, em princípio, algumas incongruências e anacronismos que comumente perpassam o tema. Num plano geral, aqueles identificados em abordagens consolidadas de toda a historiografia latino-americana decorrentes, segundo interpretação de Chiaramonte, da busca das origens das nações americanas em três lócus: o primeiro (mais comum e mais tradicional), nas "comunidades com personalidade nacional", tomadas como correspondentes aos novos Estados independentes; o segundo (e, talvez, uma conseqüência lógica do primeiro), na atuação sobretudo

\footnotetext{
${ }^{1}$ Expressão que alude às formas de identificação coletiva construídas no decorrer de um processo conflitivo, de luta entre grupos e classes portadores de interesses mais ou menos coesos. Num período de crise - como se admite ser o caso - a perda de eficácia dos mecanismos garantidores da reiteração da vida, em suas múltiplas dimensões, e a urgente necessidade de reinstaurá-los, desdobra-se no reordenamento dos parâmetros capazes de pautar atitudes e projetos alternativos de futuro, incluindo aqueles que lhes servem de substrato simbólico: os referentes de natureza identitária. (JANCSÓ, István \& PIMENTA, João Paulo Garrido. Peças de um mosaico - ou apontamentos para o estudo da emergência da identidade nacional brasileira, In: MOTA, Carlos Guilherme (org.). Viagem Incompleta. Formação: histórias. São Paulo: Ed. Senac, 2000, vol. 1, p. 143). ${ }^{2}$ Hipótese, vale frisar, que não é individual, mas cunhada no âmbito das reflexões coletivas desenvolvidas nos últimos quatro anos pelos pesquisadores do grupo temático "Brasil: fundação do Estado e da Nação (1750-1850)”, coordenado por István Jancsó, IEB/USP.
} 
do Estado (nacional), tomado como "produtor" das nações americanas; finalmente, na identidade "americana", suposto sentimento propulsor dos futuros apegos nacionais. ${ }^{3}$

Mediante tais vieses e considerando o universo flagrantemente assimétrico que constitui as Minas de finais do XVIII e inícios do XIX, assumimos a proficuidade da proposição deste historiador, ao recolocar o problema das construções identitárias em termos da multiplicidade e coexistência de identidades coletivas de diferentes tipos e dimensões, de cujo embate surgirão as grandes redefinições nacionais. ${ }^{4}$

Num plano mais específico - mas, sem dúvida alguma, articulado aos problemas gerais expostos -, a opção temática guiou-se pela crítica a interpretações consolidadas da historiografia mineira, sobretudo do século XIX e primeira metade do XX, que insistem em postular uma suposta "especificidade mineira", referida por uma rebeldia congênita, associada ao caráter libertário de seu povo ${ }^{6}$, precocemente traduzida na repulsa ao jugo português e que teria alçado a província à condição de berço da "rebelião patriótica" e da própria

\footnotetext{
${ }^{3}$ CHIARAMONTE, José Carlos. El mito de los origenes en la historiografia latinoamericana. In: Cuadernos del Instituto Ravignani. Instituto de Historia Argentina y Americana Dr. Emilio Ravignani, Universidad de Buenos Aires, $3^{\text {a }}$. Série, $n^{\circ} 1,1^{\circ}$. Sem., 1989. Para o caso da América hispânica, vale ainda as formulações de GUERRA, François-Xavier. A nação na América espanhola: a questão das origens (trad.), In: Revista Maracanan, ano 1, n ${ }^{\circ}$. 1, 1999/2000, p. 9-30.

${ }^{4}$ CHIARAMONTE, José Carlos. Metamorfoses do conceito de nação durante os séculos XVII e XVIII. In: JANCSÓ, István (org.). Brasil: Formação do Estado e da Nação. São Paulo: Hucitec; Unijuí: Fapesp, 2003, p. 61-91.

${ }^{5}$ ARRUDA, Maria A. do Nascimento. Mitologia da Mineiridade. O imaginário mineiro na vida política e cultural do Brasil. São Paulo: Brasiliense, 1990, p. 63-69.

${ }^{6}$ Respaldada em interpretações clássicas, como as de Miran Latif - que associa o "espírito liberal da Capitania" ao trabalho de lavra - de Waldemar de Almeida Barbosa, João Camilo Tôrres e de Milton Soares Campos, a tendência se reprisa em estudos mais recentes e apurados, como os de Russel-Wood, o qual, analisando a resistência colonial à imposição da autoridade metropolitana, não deixa de salientar, no caso mineiro, o fato de que "apesar de cosmopolita em alguns aspectos e graças à sua riqueza, seus habitantes não puderam destruir barreiras psicológicas de estar além das montanhas". (RUSSEL-WOOD, J. R. Precondições e precipitantes do movimento de independência da América Portuguesa. In: FURTADO, Júnia F. (org.). Diálogos Oceânicos. Minas Gerais e as novas abordagens para uma História do Império Ultramarino Português. Belo Horizonte: Editora da UFMG, 2001, p. 419-463; LATIF, Mirian de Barros. As Minas Gerais. 3a . Ed. Belo Horizonte: Itatiaia, 1991, p. 197-213; BARBOSA, Waldemar de Almeida. A verdade sobre Tiradentes. Belo Horizonte, Edição do Instituto de História, Letras e Arte, s.d., p. 158; TORRES, João Camilo de Oliveira. História de Minas. Rio de Janeiro: Ed. Record, 1963, p. 9; CAMPOS, Milton Soares. O Papel de Minas no Brasil. In: Segundo Seminário de Estudos Mineiros. Belo Horizonte: Universidade de Minas Gerais, s.d.).
} 
"nacionalidade" . Perspectiva, acredita-se, excessivamente niveladora das diversas tendências políticas que aí conviveram, respaldadas num universo material nitidamente assimétrico, reflexo do também assincrônico processo de sedimentação das experiências coletivas nesta porção da Monarquia portuguesa, implicando, do ponto de vista das modalidades da "voz nação" aí manifestas, a possibilidade de sobrevivências de usos mais antigos, convivendo e mesmo legitimando o processo de constituição política da nação.

Para efeitos da argumentação desenvolvida, assume-se que o deslocamento da Corte para a América representou acontecimento de inegáveis proporções, enquadrando a partir de novas abrangências uma situação desde antes vivenciada como "crítica" , aprofundando assimetrias internas ao "mosaico" recortado - e, portanto, implicando dinâmicas também desiguais das partes em resposta às transformações do conjunto -, criando, enfim, as condições concretas e simbólicas para a Independência. Tudo isso, tornando 1808 marco privilegiado na compreensão das prioridades que orientaram as soluções inventivas dos grupos locais em relação à construção do nacional, materializada nos projetos, expressões, comportamentos e identidades coletivas, conforme se procura demonstrar.

\section{Minas no contexto da "acomodação": os referentes das identidades coletivas}

O movimento político que, no último quartel do século XVIII, pôs em evidência a capitania mineira, confirma a relevância das transformações concretas que acompanharam a crise da mineração - a inflexão agrícola, o deslocamento do fluxo populacional para as áreas do Triângulo e do sertão mineiros, a diversificação de sua economia e de suas funções urbanas - na informação dos projetos alternativos formulados por suas elites. Favoráveis à recepção e reelaboração dos novos paradigmas políticos em circulação no mundo ocidental, estas últimas mobilizaram-se em torno da reflexão sobre as causas e soluções para a decadência aurífera, movimento do qual derivaram não apenas enfoques díspares aos formulados pelos estadistas metropolitanos, como a progressiva tomada de consciência acerca das particularidades locais das Minas, a partir da

\footnotetext{
${ }^{7}$ Na clássica interpretação de Honório Rodrigues, a associação entre 1789 e 1822 se deve ao fato de que a Independência veio consolidar os ideais dos conjurados. (RODRIGUES, José Honório. História, Corpo do Tempo. Rio de Janeiro, s.n., 1976).

${ }^{8}$ KOSELLECK, Reinhart. Crítica e Crise. (trad.). Rio de Janeiro: Eduperj/Contraponto, 1999, p. 111 e 184.
} 
qual rejeitaram as políticas prescritas pelo poder central e preconizaram meios distintos para reverter a propagada "decadência" da capitania.

É assim que, nas reflexões de administradores e memorialistas locais, bem como em boa parte das Correspondências e Oficios por estes enviadas ao governo metropolitano, denunciava-se os "abusos" cometidos pelos administradores da capitania mineira ${ }^{9}$, atribuindo-se a queda na arrecadação do fisco não à suposta infidelidade dos súditos das Minas - que, na visão do Estado metropolitano, seria a causa do extravio do ouro ${ }^{10}-$, mas aos métodos empregados na erradicação do contrabando - não contempladores da realidade local; aos problemas do atraso técnico; à necessidade de proibição do giro do ouro em pó, com a criação de uma casa da moeda em Vila Rica ${ }^{11}$; à esterilidade das lavras antigas e a necessidade de diminuição dos jornais dos escravos - que já não conseguiam extrair a mesma quantidade de ouro que antes -, bem como ao sistema de recrutamento dos "filhos das minas" para prestarem serviços em outras capitanias ${ }^{12}$. Enfim, uma realidade que insistiam em descrever pelos termos de "miséria", "carência" e "pobreza", agravada pela inércia do Estado português que, até finais do XVIII, insistira numa visão ortodoxa acerca da "decadência das Minas". ${ }^{13}$

Se por um lado tal "estado crítico" começava a informar possibilidades de alternativas políticas que passavam ao largo da tradicional adesão à casa de

${ }^{9}$ COELHO, José João Teixeira. Instrução para o Governo de Minas Gerais 1780. In: RIHGB, vol. 15, 1852, p. 257-335. Ver ainda: "Carta de Sebastião Xavier de Vasconcellos Coutinho a Martinho de Mello e Castro". Rio de Janeiro, 30 de Maio de 1791, in: RIHGB, t. 65, parte I, 1902, p. 250. ${ }^{10}$ BOXER, Carl R. A Idade de Ouro do Brasil (dores de crescimento de uma sociedade colonial). São Paulo: Cia Ed. Nacional, 1969, p. 190; SOUZA, Laura de Mello e. Tensões sociais em Minas na segunda metade do século XVIII. In: NOVAES, Adauto (org.). Tempo e História. São Paulo: Cia das Letras, 1992, p. 347-366.

${ }^{11}$ Argumentos defendidos, respectivamente, nas Instruções de Teixeira Coelho - acima citada - e pelo antigo Governador D. Rodrigo José de Meneses. (José João Teixeira Coelho, "Instrução para o Governo de Minas Gerais", 1780, op. cit.; "Exposição do Governador D. Rodrigo José de Menezes sobre o estado de decadência da Capitania de Minas Gerais e meios de remediá-lo", in: $R A P M$, ano II, abr/jun/1897, fasc. 2, p. 311-327).

${ }^{12}$ Sobre a centralidade atribuída a Minas Gerais na Defesa, Conservação e Segurança da colônia americana, refletindo-se no recrutamento de seus habitantes, ver "Instrução para Dom Antonio de Noronha, Governador e Capitão-General da Capitania de Minas Gerais”, por Martinho de Mello e Castro, 24 de janeiro de 1775, in: RIHGB, v. 6, 1844, p. 215-221.

${ }^{13}$ Sobre estas divergentes percepções da crise pelo Estado português e os súditos mineiros, ver o pioneiro trabalho de STUMPF, Roberta Giannubilo. Filhos das Minas, americanos e portugueses: identidades coletivas na Capitania das Minas Gerais (1763-1792). São Paulo: USP/Depto. de História, 2001 (Dissertação de Mestrado), p. 108-110. 
Bragança e à identidade portuguesa ${ }^{14}$, por outro, estudos recentes têm revelado a heterogeneidade do movimento, respaldada nas específicas condições de existência dos conspiradores, nas suas distintas formas de apropriação e usufruto da riqueza implicando, seguramente, concepções também distintas do evento de $1789^{15}$ e, portanto, da própria crise.

Desse modo, admite-se, compreender "a complexidade do processo político em meio ao qual Estado e Nação brasileiros passaram de virtualidades inscritas na crise à condição de realidades historicamente construídas" ${ }^{16}$, bem como as alterações no significado das identidades construídas a partir das muitas pátrias ${ }^{17}$, implica considerar as relações assimétricas entre os grupos locais e a dimensão macropolítica que, até aquele momento, conferia unidade à diversidade mapeada, servindo de substância e contorno do "nacional": ou seja, a Monarquia portuguesa, aqui pensada menos como Estado territorialmente configurado e mais como conceito fundante do próprio Estado ${ }^{18}$.

Da mesma forma, a perquirição dos referentes das identidades coletivas no desdobrar da crise impõe a consideração de algumas tendências estruturais da formação societária analisada, inscritas na esfera das tensões entre as polaridades "unidade/diversidade", "centro(s)/periferia(s)", "permanências/rupturas",

\footnotetext{
${ }^{14}$ Alternativas de futuro que, ao se desenharem, acarretariam o remanejamento das antigas referências, politizando a "identidade coletiva regional" - o "ser das Minas" -, a partir de uma específica leitura do passado por parte dos súditos mineiros: aquela marcada pelo estigma da "singularidade", dando coesão ao projeto sedicioso de 1789. (STUMPF, Roberta G., op. cit., p. 204; 223-224).

${ }^{15}$ Refiro-me, especificamente, ao trabalho de FURTADO, João Pinto. O manto de Penélope: história, mito e memória da Inconfidência Mineira de 1788-9. São Paulo: Companhia das Letras, 2002. ${ }^{16}$ JANCSÓ, István, (org.). Brasil: Formação do Estado e da Nação, op. cit., p. 16.

${ }^{17}$ Vale notar que, entre finais do XVIII e inícios do XIX, o vocábulo pátria era eivado de sentidos polissêmicos. Recorrendo ao Vocabulário de Bluteau, aparecem aí as seguintes definições de pátria, não excludentes entre si: pátria como local de nascimentos (vila, cidade ou Reino); como local de escolha de residência e atuação; como espaço de universalidade (a noção de "pátria celeste", cara ao pensamento escolástico) e pátria como espaço simbólico de utopia e liberdade intelectual (no contexto da ilustração, significando espaço de autonomia e liberdade dos sábios). (BLUTEAU, Raphael. Vocabulário Portuguez e Latino, Coimbra: Colégio das Artes da Companhia de Jesus, 1712. (ed. Fac-símile em CD-ROM, Diretoria Cultural, UERJ/Academia Brasileira de Letras, 2000, vol. VI, p. 320-321).

${ }^{18} \mathrm{O}$ que, nas palavras de István Jancsó, apenas reforça a relevância da autopercepção dos conquistadores-colonizadores da América como "portugueses, integrantes da nação estruturada em torno da Monarquia e dos valores e normas societárias que, peculiares, diferenciavam-na de todas as outras", tornando, de outra forma, a "história do mosaico luso-americano inseparável da história de sua moldura, isto é, do Estado que esteve à frente de sua formação". (JANCSÓ, István, "Independência, Independências", in: JANCSÓ, István (org.). Independência: História, Historiografia. São Paulo: Hucitec/ Fapesp, 2005, p. 19-21).
} 
em seus diversos níveis e dimensões. A primeira delas, o fraco enraizamento de vínculos identitários de tipo regional, capazes de remeterem à ligação com uma espacialidade especificamente "mineira", fato este contrastante com outras Capitanias de colonização mais antiga ${ }^{19}$. Tal constatação pareceu-nos compreensível à luz do relativamente recente e rápido processo de ocupação do território mineiro - não dando tempo para que os vínculos sociais e com a terra se sedimentassem -, adensado pela ausência de base familiar, uma vez que a colonização fora aí protagonizada por "moços solteiros, que nada tinham a perder" ${ }^{20}$. Além disso, apesar de sempre terem aí convivido atividades agropastoris e mercantis, a mineração não se caracteriza como um tipo de atividade que implique desenvolvimento de vínculos duradouros com a terra. ${ }^{21}$

Neste sentido, a história política da capitania e depois província mineira não se singulariza por conflitos esgrimidos no campo da genealogia - como em outros contextos da América portuguesa ${ }^{22}$ - e, embora comportando situações peculiares - como aquela dos criadores de gado do sertão, cuja maior identificação com a terra era expressa pela designação de "poderosos do sertão"²3

\footnotetext{
${ }^{19}$ Refiro-me aos casos exemplares da Bahia e Pernambuco, onde era forte a tradição de "nobreza da terra". Sobre os mesmos, ver, respectivamente: JANCSÓ, István. Na Bahia contra o Império: História do ensaio de sedição de 1798. São Paulo: Hucitec/Salvador: EDUFBA, 1996; MELLO, Evaldo Cabral de. A fronda dos Mazombos. Nobres contra mascates. Pernambuco (1666-1715). São Paulo: Cia das Letras, 1995, e, mais recentemente, BERNARDES, Denis Antonio de Mendonça. O patriotismo constitucional: Pernambuco, 1820-1822. São Paulo: Hucitec, 2006.

${ }^{20}$ SOUZA, Laura de Mello e. Norma e Conflito. Aspectos da História de Minas no Século XVIII. Belo Horizonte: Ed. UFMG, 1999, p. 175.

${ }^{21}$ Já em 1780, o ilustrado governador das Minas, D. Rodrigo José de Menezes reconhecia esta relação direta entre a dependência dos "fundos de terra" e o apego à "Sociedade", bem como "obediência às Leis". Naquele momento, contudo, contrapunha a situação do "mineiro" à do "negociante", argumentando ser este último o responsável pelo contrabando, por não temerem "perder o patrimônio de que os faz viver". ("Exposição do Governador D. Rodrigo José de Menezes sobre o estado de decadência da Capitania de Minas Gerais e meios de remediá-lo", op. cit., p. 311-327).

${ }^{22}$ MELLO, Evaldo Cabral de. O nome e o sangue. Uma fraude genealógica no Pernambuco colonial. São Paulo: Cia das Letras, 1989.

${ }^{23}$ Mesmo nestes casos, contudo, o apego ao local de domicílio e a maior sedimentação dos laços de solidariedade entre potentados locais e agregados, não implicava, necessariamente, vínculos com uma espacialidade tipicamente mineira - gravitando a região muito mais em torno das capitanias setentrionais, pelos vínculos de comércio, políticos e mesmo parentesco - e, tampouco, do orgulho de "ser português". (SILVA, Ana Rosa Cloclet da. Identidades em Construção. O processo de politização das identidades coletivas em Minas Gerais (1792-1831). São Paulo: USP/FFLCH, Dep. de História, 2007. (Relatório de Pós-Doutoramento). Sobre o caso específico dos 'poderosos do sertão", ver observações de RUSSEL-WOOD, J. R., "Identidade, etnia e autoridade nas Minas Gerais do século XVIII: leituras do Códice Costa Matoso, in: Varia História, Belo Horizonte, n.
} 
- a tradição dos "filhos da terra" não se constituiu aí no vínculo identitário de maior poder coesivo, profícuo na compreensão dos embates travados entre suas diferentes partes, bem como nas soluções de compromisso alinhavadas entre estas e o poder central.

Daí justificar-se que, embora a ruptura com o Estado metropolitano e com a identidade política coletiva vigente - a "portuguesa" - configurasse uma das alternativas possíveis aos conspiradores de 1789, a certeza quanto ao "outro" a que se opunham não tinha como contrapartida uma nova identidade capaz de expressar adequadamente o contorno da comunidade política que legitimava as ações encetadas, o que é indicado, segundo estudo de Stumpf, pela ampla variação de termos usados para referi-la - "Americanos", "brasileiros", "filhos das Minas", "americanos portugueses", "portugueses" - cuja coexistência num único momento denuncia a própria heterogeneidade da sociedade mineira. ${ }^{24}$

Mediante a magnitude e abrangência da crise então externada, o Estado metropolitano viu-se na incumbência de reavaliar as políticas reformistas, tarefa que toma fôlego com a subida de D. Rodrigo de Sousa Coutinho ao Ministério dos Negócios Ultramarinos, em 1796. Amigo do novo governador nomeado para as Minas e convertido no principal projetor e articulador das políticas reformistas dos reinados mariano e joanino ${ }^{25}$, Sousa Coutinho propôs medidas de proporções efetivamente "revolucionárias", direcionadas à estrutura administrativa, tributária e orgânica da capitania ${ }^{26}$, inseridas no seu plano mais geral para ativar a suposta "reciprocidade de interesses" entre as porções imperiais.

Desde então, o perfil das soluções de compromisso alinhavadas entre os grupos locais e a dimensão macropolítica organizadora do "mosaico mineiro" balizou-se por um sentimento em relação a 1789, que expressava a percepção daqueles "magnatas das Minas" acerca das transformações materiais que, ao afetar o universo simbólico correspondente a uma sociedade que se pretendia estamental, configurava-se em riscos à preservação de autonomias longamente

\footnotetext{
21, jul/1999, p. 113-114).

${ }^{24}$ STUMPF, Roberta G., op. cit., p. 201.

${ }^{25}$ Sobre o estadista luso ver: Marquês de Funchal. O Conde de Linhares. Dom Rodrigo Domingos Antonio de Sousa Coutinho. Lisboa: Typ. Bayard, 1908, p. 29-30;

${ }^{26}$ COUTINHO, D. Rodrigo de Sousa. Memória sobre o melhoramento dos Domínios de Sua Majestade na América. In: Brasília, vol 4, s.d., p. 405-422.
} 
constituídas, comprometendo ainda os próprios referenciais de estratificação social. Sentimento, aliás, que já havia orientado a repulsa das elites mineiras à Instrução de Mello e Castro ao Governador Barbacena, e estivera na base do movimento sedicioso ${ }^{27}$.

Neste contexto, a despeito da grande distância entre a "mudança socioeconômica e a elaboração da política" reformista ${ }^{28}$, os grupos chamados a participar ativamente da reorientação da política imperial dariam transparência às condições concretas da existência que passavam a informar os termos da adesão à Monarquia portuguesa, bem como as possibilidades de reiteração de estruturas societárias que tinham por permanentes, mas cujo controle lhes escapava.

Encaminhando evidências e sugerindo recomendações aos reformistas do Reino, os membros das Câmaras municipais, junto com instruções de "brasileiros eruditos" acerca da melhor forma de aproveitamento do potencial natural da Capitania, deram um contorno mais nítido ao princípio genérico da reciprocidade de interesses entre as partes, fundando os termos sobre os quais se processaria a negação da condição colonial, a partir de 1808, bem como os referenciais que dariam tangibilidade às novas identidades coletivas em construção.

Daí que, em vez de uma pretensa "acomodação" a projetos cujo referencial político era o Império ${ }^{29}$, o contexto recortado continuava esgarçando o caráter de negociação da autoridade metropolitana, cuja eficácia condicionava-se à viabilização de demandas específicas e diversificadas, à preservação de situações de poder e referenciais políticos de antigos tipos que, no limite, implicavam condições de resistência aos próprios desígnios do poder central, caso este ameaçasse desestabilizá-las.

Até onde pudemos averiguar, esta negociação pautava-se por dois objetivos básicos, para os quais convergiam as reivindicações dos grupos em causa. Por um lado, o desenvolvimento das potencialidades locais - já à luz da nova realidade socioeconômica da Capitania - sob as quais passavam a vislumbrar a própria

\footnotetext{
${ }^{27}$ A Instrução do então Ministro do Reino e Ultramar afastava a plutocracia local dos postos administrativos, o que significava afetá-la tanto financeiramente - já que a posse de cargos era a forma de participar de esquemas bem remunerados -, quanto no plano das representações simbólicas, que diferenciavam os administradores do restante da população. (MAXWELL, K. A Devassa da Devassa: a Inconfidência Mineira, Brasil - Portugal, 1750-1808. 2a. Ed., Rio de Janeiro: Paz e Terra, 1978, p. 130-133; STUMPF, Roberta Giannubilo, op. cit., p. 150-170).

${ }^{28}$ MAXWELL, K. op. cit., p. 240.

${ }^{29}$ Idéia esta consagrada por Maxwell para definir as relações entre elites mineiras e poder metropolitano, entre 1795-1808. ( MAXWELL, K. A Devassa da Devassa, op. cit., cap. 8).
} 
especificidade de suas condições sociais ${ }^{30}$, definida pela maior proximidade com o que entendiam ser a Capitania "eleita" pelo soberano e, portanto, justificadora de maiores autonomias e competências políticas. ${ }^{31}$

Daí o reenfoque do diagnóstico decadentista - imputado à "ignorância dos mineiros" 32 e às dificuldades e altos custos impostos ao seu trabalho ${ }^{33}$, bem como à "falta de indústria, ociosidade, vícios da plebe, luxo sem meios, e bazofia mesmo da maior parte dos particulares" ${ }^{\prime 34}$-, ancorando as políticas reformistas nos novos ideais de prosperidade, trabalho e civilização $o^{35}$, justificando solu-

\footnotetext{
${ }^{30}$ CAVALCANTE, Berenice. Os 'letrados' da sociedade colonial: as Academias e a cultura do Iluminismo no final do Século XVIII. In: Acervo, Revista do Arquivo Nacional, vol. 8, n. 1-2, jan/ dez de 1995, p. 53-67; LORELAI, B. Kury e MUNTEAL FILHO, Oswaldo. Cultura Científica e sociabilidade intelectual no Brasil setecentista: um estudo acerca da Sociedade Literária do Rio de Janeiro. In: Acervo, idem, p. 105-139.

${ }^{31}$ Já em 1799, o memorialista Vieira Couto discorria sobre as particularidades da Capitania, as causas da decadência e os métodos que deveriam ser aplicados para revertê-la. Clamava, então, para que a Rainha Maria I lançasse "os olhos sobre a mais rica e a mais formosa porção das vossas possessões, uma terra extremamente fértil na sua superfície, cheia de variadas produções e vária em climas, rica nas suas entranhas e prenhe de todos os metais", síntese do próprio "Brasil, que se honra de vos ter por Senhora, e que bem merece os vossos paternais cuidados". (COUTO, José Vieira. Memória sobre a Capitania de Minas Gerais, seu território, clima, e produções metálicas; sobre a necessidade de se restabelecer e animar a mineração decadente do Brasil; sobre o comércio e exportação dos metais, e interesses régios, de 1799, In: Revista Trimestral de História e Geografia ou Jornal do Instituto Histórico e Geográfico Brasileiro, Rio de Janeiro: Typ. De João Ignácio da Silva, Tomo XI, 2a . Ed., 1871, p. 300-320). Esta mesma visão impregnava, progressivamente, os diagnósticos dos administradores da Capitania, sendo precocemente emitida pelo Governador Rodrigo José de Menezes, em 1780 - quando então se referia a Minas como uma Capitania "diferente de todas as demais" - e, posteriormente, reprisada na própria Instrução de Melo e Castro ao Visconde de Barbacena, que a tomava como "uma das mais importantes" do Brasil. (Ver, respectivamente: "Exposição do Governador D. Rodrigo José de Menezes sobre o estado de decadência da Capitania de Minas Gerais e meios de remediá-lo", op. cit., p. 311; "Instrução para o Visconde de Barbacena, Luis Antonio Furtado de Mendonça, governador e Capitão Geral da Capitania de Minas Gerais", de Martinho de Mello e Castro, escrita em 29 de janeiro de 1788. RIHGB, t. 6, vol. 6, 1844. p. 12).

${ }^{32}$ COUTO, José Vieira. Memória sobre a Capitania de Minas Gerais, seu território, clima, e produções metálicas; sobre a necessidade de se restabelecer e animar a mineração decadente do Brasil; sobre o comércio e exportação dos metais, e interesses régios, de 1799, op. cit.

${ }^{33}$ OTTONI, José Eloi. Memória sobre o estado atual da capitania de Minas Gerais, de 1798. In: Anais da Biblioteca Nacional do Rio de Janeiro, XXX, 1908, p. 3030-318.

${ }^{34}$ SAAVEDRA, Basílio Teixeira de, "Informação da Capitania de Minas", de 30 de março de 1805. RAPM, 2: 637-83, p. 675-677.

${ }^{35}$ CHAMON, Carla Simone. Festejos Imperiais: festas civicas em Minas Gerais (1815-1845). Bragança Paulista: EDUSF, 2002, p. 68-80.
} 
ções que deveriam passar pelos "meios mais suaves", combinando "sempre o interesse da causa pública com a conservação dos particulares". ${ }^{36}$

Tais valores e referenciais, por sua vez, apareciam mesclados aos anseios por signos de distinção definidos pelo centro do Império, que remetiam a critérios de hierarquização próprios ao Antigo Regime português, prolongados no território da América. A tais anseios, a própria Coroa não era alheia, procurando compatibilizá-los com os propósitos de dinamização do sistema, acalentados no bojo do reformismo ilustrado.

Era assim que, em Ofício de 1797, o Governador das Minas, Bernardo José de Lorena, comunicava-se a D. Rodrigo de Sousa Coutinho o recebimento de uma carta determinando-lhe, por ordem da Rainha, "aumentar nesta Capitania o uso e consumo de todas as produções naturais e manufaturas desse Reino, usando de todos os meios, exceto os da violência", a fim de conseguir tão desejado fim, "distinguindo e favorecendo com particularidade os que introduzirem e consumirem maior quantidade de vinhos, panos, sedas e trastes de luxo manufaturados em Portugal". ${ }^{37}$

Por outro lado, coerentes com a lógica de uma sociedade marcada pela "vontade da distinção" e trespassada pelo reconhecimento da "escravidão como um valor" ${ }^{\prime 38}$, proprietários e administradores das Minas filtraram as políticas reformistas encaminhadas pelo Estado metropolitano, evitando agravar a já difícil compreensão do lugar de cada um, num universo cujos critérios de ordenação eram díspares e flexíveis. Neste ponto, vale lembrar que, além do elevado percentual escravo - estimado em $46,4 \%$ da população total, para o ano de $1805^{39}$ - Minas contava com um contingente de negros e pardos, livres e forros em permanente expansão e integração às diversas profissões e atividades, ocupando predominantemente os "setores menos privilegiados", como o "artesanato, serviços em geral e jornaleiros”, mas também na condição de proprietários de escravos, ligados ao comércio, ou em cargos civis e militares. ${ }^{40}$

\footnotetext{
36 “Registro de Cartas do Governador Pedro Maria Xavier de Atayde e Mello às Câmaras, Juízes e outras autoridades da Capitania", 19 de dezembro de 1807, in: APM, Seção Colonial, cód. 315, p. 42. 37 "Registro de Ofícios do Governador às secretarias de Estado", Vila Rica, 10 de março de 1798. (APM, SC, Cod. 276 p. 25). (grifo meu).

${ }^{38}$ SILVEIRA, Marco Antonio. O Universo do Indistinto. Estado e Sociedade nas Minas Setecentistas (1735-1808). São Paulo: Hucitec, 1997.

${ }^{39}$ MAXWELL, K., op. cit., p. 302.

${ }^{40}$ COSTA, Iraci Del Nero da. Arraia-Miúda. Um Estudo sobre Não-Proprietários de Escravos no Brasil. São Paulo: MGSP Editores, 1992, p. 93.
} 
Na conjuntura política da crise, este quadro social ganharia complexidade, dado que a perspectiva dos benefícios e autonomias contagiava, também, a população livre pobre da capitania, influindo nos seus ânimos, conforme indicado no Ofício de 1798 dirigido a D. Rodrigo de Sousa Coutinho, pelo então Governador Bernardo José de Lorena. Referindo-se a umas "petições (...) dos Homens Pardos e Pretos libertos desta Capitania", relativas à concessão de sesmarias, alertava o Ministro do Ultramar sobre o "grandíssimo excesso em número que levam Pardos e Pretos sobre os Brancos nesta Capitania", acrescendo "ser muito prejudicial, se V. Majestade favorecer mais em geral àquela casta de gente, do que a tem já favorecido, pelas suas sábias e justíssimas Leis (...)". ${ }^{41}$

Além disso, o contexto assinalado seguramente inquietava proprietários brancos e dirigentes das Minas, mediante a então recente sublevação dos escravos ocorrida nas "Antilhas" ${ }^{42}$, em 1792, e a não menos inquietante experiência baiana, de 1798. Esta última, especialmente, parece ter surtido efeitos muito mais concretos no cotidiano da capitania, do que o considerado por Maxwell, mobilizando aqueles grupos no sentido de conter os ensaios de insurreição que, naquele momento, foram capitaneados justamente por elementos pardos da população ${ }^{43}$, os quais, integrando-se econômica e socialmente, não puderam fugir ao "estigma da escravidão", representando por isso um permanente risco de radicalização do processo político em curso. ${ }^{44}$

É, portanto, a empiria de condições concretas da existência que informava os sentidos básicos de alteridade para aquelas "elites" de vários tipos e planos, em

\footnotetext{
41 "Registro de Ofício do Governador Bernardo José de Lorena ao Ministro D. Rodrigo de Sousa Coutinho", de 17 de abril de 1798. (APM, Seção Colonial, Cód. 276, p. 26v).

${ }^{42}$ Termo utilizado pelo próprio Bernardo de Lorena, para se referir ao episódio de São Domingos. (idem).

${ }^{43}$ Registrava-se, por esta época, a insubordinação dos pardos milicianos do Distrito de Itabira do Mato Dentro (região metalúrgica de Minas), seguindo auto do Juiz Ordinário Manuel Teixeira da Silva, de Vila Nova da Rainha. (APM, SG, CX 40, DOC 46, P. 1, 1798). Ver ainda vários documentos que aludem à atuação de Miguel Ferreira de Souza, capitão do Regimento dos Pardos de Mariana que, em 1798, fora acusado de andar "espalhando a cizânia" de que o governador das Minas tinha ordem régia "para que os pardos cativos sejam forros e igualmente tudo o mais, até os próprios negros depois de haverem servido dez anos". ( $A P M$, SG 40, docs. 45 e 52)

${ }^{44} \mathrm{O}$ potencial de desestabilização da ordem representado pela ação de pardos, mulatos e negros forros, não foi exclusiva de Minas. Analisando os casos do Rio de Janeiro e da Bahia, no período colonial, Silvia Lara chega a conclusões semelhantes, especialmente quando se trata de considerar a perspectiva das autoridades coloniais. (LARA, Silvia H., "Reminiscências setecentistas. Escravidão, Cultura e Poder na América Portuguesa”. Campinas: Unicamp/IFCH, 2004. (Tese apresentada para o concurso de Livre-Docência). Sobre a atuação destes segmentos sociais na Bahia, no contexto de formação do novo Estado nacional, ver: REIS, João José. Rebelião Escrava no Brasil: a história do levante dos malês (1835). 2ª . Ed. São Paulo: Brasiliense, 1987, p. 37-63.
} 
recusa aos quais se organizaram temporária e precariamente: os extremos do despotismo e da anarquia, ambos fincados num comum desejo de preservação e ampliação de autonomias longamente conquistadas, bem como de reprodução de estruturas societárias que tinham por permanentes, mas cujo controle lhes escapava. ${ }^{45}$

Já na fala do então vereador Dr. Diogo Pereira de Vasconcelos, pronunciada em sessão solene da Câmara de Vila Rica, em plena "Festa do Despotismo", a relação típica de sociedades do Antigo Regime era reafirmada em nome não apenas da devida obediência ao trono luso e das "leis fundamentais e as da sucessão", mas dos "motivos de interesse", das "recompensas que devem esperar os vassalos beneméritos". ${ }^{46}$

Esta condição comum - que englobava tanto o ser "Brasileiro" (expressão que povoa seu discurso), quanto o ser um "povo português" (expressão que aparece sob a ressalva "assim vos devo chamar") -, embora expressasse um sentimento de pertencimento político mais geral, próprio ao Antigo Regime, politizava-se mediante a conotação de igualdade que imprimia aos habitantes dos dois hemisférios, já que não existiria qualquer "diferença entre uns e outros; todos têm o mesmo Rei, a mesma Pátria comum”, sendo, portanto, merecedores de iguais benefícios ${ }^{47}$. Nestes termos - talvez por contingência de um estágio da crise em que o próprio Estado português convertia-se no

\footnotetext{
${ }^{45}$ Vale notar que, embora representassem uma ameaça à ordem e aos parâmetros de estratificação social - derivando a estratégia comum de proprietários e autoridades das Minas de empurrar as coevamente designadas "classes ínfimas" para uma condição comum marginal, associada ao cativeiro -, estes elementos não deixaram de expressar um contraponto de peso aos excessos de despotismo cometidos pelo poder central - acionado através de alianças e conchavos políticos com as camadas dominantes, em diversos momentos em que estas tiveram suas "autonomias" ameaçadas -, nem, tampouco, de preservar referenciais identitários de tipo alternativos, convivendo com a identidade portuguesa. Sobre este ponto, ver: ANDRADE, Marcos Ferreira. Rebeliões escravas na Comarca de Ouro Preto. In: Vária História, Belo Horizonte, n. 17, março de 1997, p. 237-257. Sobre a interferência destes padrões de inserção social sobre o plano das identidades coletivas em construção ver: SILVA, Ana Rosa Cloclet da. Identidades em Construção, op. cit., cap. 4.

${ }^{46}$ Fala do Dr. Diogo Pereira de Vasconcelos, em sessão solene da Câmara de Vila Rica, em regozijo pelo fracasso da Inconfidência, 22 de maio de 1792. APM, Fundo/Coleção-Inconfidentes. O documento está publicado na RAPM, ano I, julho/set 1896, p. 401-415.

${ }^{47}$ Esta última convicção justifica as críticas que, em 1806, o então Governador Ataíde e Mello dirigia aos pesados direitos pagos sobre gêneros importados pela Capitania - exemplo de "fidelidade" e "patriotismo" e da arrecadação do Real Erário - bem como as ressalvas com as quais os membros da Câmara de Ouro Preto receberam o Alvará de 20 de outubro de 1795. (Ver, respectivamente: "Ofícios do Governador às Secretarias de Estado e respostas às Ordens Régias", pelo Governador Pedro Maria Xavier de Ataíde e Mello, de 11 de janeiro de 1806. (APM, SC 303, p. 51 a 53); "Parecer enviado pela Câmara de Ouro Preto ao Visconde de Barbacena", sobre Alvará de 1795 (APM, Fundo CMOP, cx 67, docs 54 e 69).
} 
cerne das insatisfações, impondo o exercício do poder à reflexão - é possível que já se configurasse como parte das "condições de possibilidades" daqueles "filhos das Minas" a visão do Brasil como referente das identidades coletivas. Seu potencial de politização, contudo, estava fincado na invertida forma de negação da dependência colonial, expressa não pela tentativa de ruptura com Portugal, mas pela afirmação das condições da unidade.

\section{A Corte na América e o patriotismo imperial: a reconfiguração pela adesão}

A transfe rência da Corte para o Rio de Janeiro, em 1808, constitui marco fundamental da crise do Antigo Regime português. Inaugurando um período de "inédita aceleração histórica no mundo luso-americano", implodindo com o próprio conceito de metrópole e metropolitanos ${ }^{48}$, gestaram-se, desde então, as condições concretas para a Independência, em 1822.

No que concerne aos projetos políticos formulados pelo âmbito dos estadistas portugueses, cabe notar que 1808 impõe uma inflexão fundamental à idéia do "vasto Império luso-brasileiro" 49 - dado que Portugal deixava de ser o "ponto de reunião" das partes e o "assento da Monarquia" -, implicando a necessidade de articular as novas bases sociais de sustentação da autoridade régia na sua nova sede, alterando as "tradicionais rotas de peregrinação" ${ }^{50}$ no espaço imperial e, no limite, impondo repensar os próprios fundamentos simbólicos da Monarquia.

Para os objetivos da discussão aqui proposta, interessa frisar que 1808 teve impacto decisivo sobre a "percepção que os homens da época tinham da adequação do Estado português ao novo equilíbrio entre suas diferentes partes", implicando que a multiforme experiência política acumulada pelas elites locais perdesse eficácia, por razões antes impensáveis ${ }^{51}$. Assim, impondo uma crescente complexidade da vida - econômica, política, social e cultural - que

\footnotetext{
${ }^{48}$ JANCSÓ, István \& PIMENTA, João Paulo Garrido. Peças de um mosaico, op. cit.

${ }^{49}$ Sobre a gestação deste projeto no bojo da Ilustração luso-brasileira, ver: LYRA, Maria de Lourdes Vianna. A utopia do poderoso Império: Portugal e Brasil: bastidores da política, 1798-1822. Rio de Janeiro: Sette Letras, 1994; SILVA, Ana Rosa Cloclet da. Inventando a Nação. Intelectuais ilustrados e estadistas luso-brasileiros na crise do Antigo Regime Português (1750-1850). São Paulo: Hucitec, 2006.

${ }^{50}$ ANDRESON, Benedict. Nação e consciência nacional. São Paulo: Ática, 1989.

${ }^{51}$ JANCSÓ, István \& PIMENTA, João Paulo Garrido. Peças de um mosaico, op. cit.
} 
afetaria diretamente a capitania mineira, instalavam-se novas abrangências, no interior das quais as identidades foram construídas e politizadas.

Neste sentido, um primeiro ponto a ser considerado é a percepção dos atores acerca do caráter memorável do acontecimento, que não apenas acentuaria fortemente a idéia da especificidade do continente americano no conjunto do Império português, como lhe conferia uma nova dignidade histórica, tornando o Brasil passível de ser pensado não como justaposição, mas como síntese de suas partes, como corpo político dotado de feição própria no interior da Monarquia portuguesa.

De modo geral, ao inegável sentimento de "orfandade" pelo qual foram tomados os súditos peninsulares ${ }^{52}$, contrapunham-se as entusiásticas expectativas dos coloniais com a situação criada, nutridas pela percepção de que a proximidade ao centro decisório do poder poderia trazer-lhes benefícios bem concretos e uma maior possibilidade de participação na "gestão da coisa pública".

Esta euforia generalizada traduzia-se nas adesões dos grupos regionais às reformas encaminhadas pelo ministério Linhares e ao referencial político a partir de então veiculado, expresso pelas noções de "vasto", "novo" e "grande" Império do Brasil $l^{53}$. Uma idéia que "conferia ao presente funções de fundação mítica, capaz de orientar o olhar para o futuro em um momento carregado de profundas incertezas". ${ }^{54}$

É neste sentido que o Correio Brazilienze, periódico editado em Londres entre 1808 e 1822 por Hypólito José da Costa, com ampla circulação no mundo ocidental, interpretava a transferência da Corte como o início de um novo tempo, associando as medidas de abertura do comércio colonial adotadas por D. João VI, em 1810, à representação da abolição do "Antigo sistema colonial", e à inauguração de uma nova era ${ }^{55}$.

Também nas correspondências dirigidas por D. Rodrigo de Sousa Coutinho a José Bonifácio de Andrada e Silva - mentor de muitas das reformas

\footnotetext{
${ }^{52}$ Sobre as percepções diferenciadas da crise, externadas pelos súditos do Reino e os americanos, ver SILVA, Ana Rosa Cloclet da. Inventando a Nação, op. cit., p. 212-245.

${ }^{53}$ LYRA, Maria de Lourdes V., op. cit., p. 118-119.

${ }^{54}$ ARAUUJO, Valdei Lopes de. A experiência do tempo. Modernidade e historização no Império do Brasil (1813-1845), PUC/RJ, 2003 (tese de doutoramento).

${ }^{55}$ Correio Braziliense. Londres, Tomo I, vol 2, 1808, p. 123. A respeito desta discussão, ver: JANCSÓ, István Jancsó \& SLEMIAN, Andréa. Um caso de patriotismo imperial. In: Correio Braziliense ou Armazém Literário, vol. XXX/ Hypólito José da Costa. São Paulo: Brasília: Imprensa Oficial do Estado, 2002, Tomo I, p. 605-667.
} 
encaminhadas a partir da nova sede da Monarquia e principal encarregado de continuar a obra da "restauração" em Portugal - evidenciava-se o otimismo diante das transformações em curso, interpretadas como sinalizadoras da própria "emancipação do Brasil”, a qual, segundo o Ministro, haveria de ser muito útil a Portugal, "não obstante tudo que inquieta os Visionários, que seguem os princípios do Sistema Mercantil (...)". 56

Este mesmo otimismo contagiava os habitantes das Vilas sediadas em diferentes partes da América portuguesa. As correspondências enviadas por suas Câmaras ao Rio de Janeiro deixam claro o nexo estabelecido entre a regeneração da Monarquia e as potencialidades do Novo Mundo, cujo aproveitamento demandava a presença régia. É neste sentido que os camarários de Vila Rica arguravam-se "venturosos, não só pela Prudentíssima, e Régia Escolha que Teve em Querer Residir entre Vassalos, que desde o princípio do Século deram sempre evidentes provas de sua fidelidade aos Augustos Predecessores de Vossa Alteza", como por esperarem "haver prosperar Um País o mais interessante do Trono Português, Residindo nele Um Príncipe de tão raras e Brilhantes Virtudes, quais adornam a Real Pessoa de Vossa Alteza a quem rogamos Queira Aceitar os nossos sinceros votos, e Certificar-se de nossa rendida Vassalagem". ${ }^{57}$

Entretanto, embora esta expectativa geral induzisse o apoio imediato às "políticas pragmáticas" destinadas a fixar as bases da Monarquia em sua nova sede, fortalecendo ainda aquele sentimento de "Patriotismo" pelo qual aderiam ao referencial de pertencimento político mais geral - o Império - bem como à identidade de "Verdadeiros Portugueses" 58 , há que considerar o forte conteúdo retórico envolvido nestes argumentos pois, o que de fato se nota é que 1808 representou um marco no despertar dos colonos "para os propósitos e medidas políticas que atingiam diretamente" suas localidades, sem procurar ligá-los, necessariamente, "aos destinos do país como um todo" 59 . Além disso, a proximidade do Monarca não deveria interferir nas suas ingerências locais, justificando a

\footnotetext{
${ }^{56}$ Carta de D. Rodrigo de Sousa Coutinho, a José Bonifácio, queixando-se da injustiça que está sofrendo e comentando sobre as minas. Rio de Janeiro, 26 de abril de 1810. (BNRJ/MN, $\mathrm{I}-4,30,38)$.

${ }^{57}$ ANRJ, Fundo Negócios de Portugal, MR, Correspondências com as Províncias, cx 642, pacte. 2, doc 69 .

58 "Representação da Câmara de São João del Rei”, de 27 de fevereiro de 1808. In: As Câmaras Municipais e a Independência, vol 2, Rio de Janeiro: Arquivo Nacional, 1973, p. 323.

${ }^{59} \mathrm{CHAMON}$, Carla Simone Chamon. Op. cit., p. 68.
} 
série de reivindicações pela preservação de administradores nos seus respectivos cargos, bem como por uma maior competência de poderes locais.

Ilustrativo deste fato foram as controvérsias geradas na Vila de Pitanguy ${ }^{60}$, por ocasião da eleição do procurador local, "que houvesse de ir beijar as mãos de Sua Alteza Real", quando de sua chegada no Rio de Janeiro. Percebendo no evento oportunidade de encaminhar suas demandas específicas, fizeram do procurador eleito - Dr. João Antonio da Silva Vieira - portador, além da procuração rendendo "vassalagem, obediência e fidelidade dos Povos da Vila", de uma "carta de ordens" que rogava a "S. Alteza diversas súplicas em nome do Conselho", dentre as quais: a confirmação do foral da Vila, de acordo com a sesmaria concedida por Ordem Régia; a conservação do Desembargador e Corregedor Geral da Comarca de Sabará (Pereira da Cunha), no mesmo cargo; a abolição do uso de propinas aos Vereadores e, em compensação, a concessão de honras e privilégios aos que servirem como Vereadores no Senado; a decisão dos conhecenças em benefício dos Povos, por serem exorbitantes (...); finalmente, a divisão do Termo de Pitanguy, no Poente do Rio São Francisco, com Tamanduá". ${ }^{61}$

A carta não chegara ao seu destino, por "ser o tempo impróprio", segundo o procurador ${ }^{62}$. Mas também não chegaria o "donativo de seiscentos mil réis, das rendas de aferições e cabeças" do Conselho, previsto na Procuração. A decisão foi acordada após intenso debate entre os vereadores, por causa das "precárias condições pecuniárias do Conselho" $"$, bem como do povo, sobrecarregado de impostos, entre os quais pesava o subsídio voluntário instituído a pretexto da reconstrução de Lisboa e que ainda vigorava ${ }^{64}$. Assim, entre a oferta destinada a auxiliar nos gastos com a viagem de D. João VI e sua aplicação nas despesas

\footnotetext{
${ }^{60}$ Criada em 1715 e administrativamente inserida na Comarca do Rio das Velhas. (CARVALHO, Theophilo Feu de. Comarcas e Termos. Creações, suppressões, restaurações, encorporações e desmembramentos de comarcas e termos, em Minas Gerais (1700-1915). Belo Horizonte: Imprensa Oficial do Estado, 1922, p. 63).

${ }^{61}$ MENDES Júnior, Onofre. Um beija-mão que provoca barulho em Pitangy. In: RAPM, Ano XXII, 1928, pp.149-158.

${ }^{62}$ Aludia à época das chuvas, que interditavam muitas das estradas e caminhos das Minas.

${ }^{63}$ Pitanguy - que depois se tornaria um dos principais entrepostos comerciais de Minas com o Rio de Janeiro - passava, naquele momento, pelos efeitos da crise mineradora, voltando suas vistas para a pecuária e a agricultura, principalmente a de mandioca. (PAIVA, Clotilde Andrade. População e Economia nas Minas Gerais do Século XIX. São Paulo: USP, Depto de História, 1996. (Tese de doutoramento), p. 116)

${ }^{64}$ Idem, p. 153.
} 
atuais do Conselho, optou-se pela segunda alternativa demonstrando, neste episódio corriqueiro, julgamento progressivamente consolidado entre os grupos locais: o de que a melhor forma de concorrerem para o sucesso do Império, era cuidando da prosperidade de suas partes. ${ }^{65}$

Extensivo a outras partes da América portuguesa, o raciocínio acima nos permite concluir que o vislumbrado pelos diversos grupos de proprietários era antes a prosperidade de suas respectivas capitanias - quando não de regiões específicas das mesmas -, embasados que estavam numa percepção fragmentada e geograficamente localizada da realidade colonial ${ }^{66}$. Daí procurarem exaltar suas vantagens naturais, destacando a forma como elas poderiam ser úteis ao desenvolvimento do Império. ${ }^{67}$

Além disso, é preciso reter que as expectativas positivas com a vinda da Corte não ofuscaram o potencial de conflito interno que a nova situação instalava. Grosso modo, é possível dizer que, se por um lado as iniciativas do governo joanino contribuíram para gestar uma atmosfera ideológica avessa à uniformidade de interesses entre os habitantes dos dois hemisférios - acentuando ainda a rivalidade entre os membros do Governo do Rio de Janeiro - por outro, a redefinição do equilíbrio político entre as capitanias, que até então se relacionavam horizontalmente, situando o Rio de Janeiro como novo centro

\footnotetext{
${ }^{65}$ Em 1810, a Câmara de Sabará encaminharia Requerimento pela conservação do Intendente da Real Casa de Fundição do ouro da dita Comarca, o Dr. José Teixeira da Fonseca Vasconcelos, "que tem felicitado os Povos dela, regendo-os com distinção, prudência e sabedoria", evitando os extravios do ouro em pó pelo franqueamento de "Moedas nestas Minas". Justificando tal graça "que de eqüidade não se nos deve negar", afirmavam estarem "a pedir ainda aquilo, que pode bem concorrer para Sua maior felicidade", sendo esta uma forma de concorrerem para a "conservação de uma parte da felicidade" geral. ("Representação da Câmara da Vila de Nossa Senhora da Conceição do Sabará", de 28 de novembro de 1810, In: As Câmaras Municipais e a Independência, vol 2, op.cit., p. 267).

${ }^{66}$ Marques dos Santos identifica esta peculiar apreensão do espaço e da sociedade colonial por parte dos Conspiradores de 1794, em contraposição à visão global do Império, formulada no âmbito do reformismo metropolitano. (SANTOS, Afonso C. Marques dos. No Rascunho da Nação Inconfidência no Rio de Janeiro. Rio de Janeiro: Secretaria Municipal de Cultura, Turismo e Esportes, Departamento Geral de Documentação e Informação Cultural, 1992, p. 112-113).

${ }^{67}$ É o que registra conforme registrado a Memória de Francisco Manoel da Cunha, enviada do Espírito Santo ao Conde de Linhares, na qual descreve o Rio Doce (que nascendo em Minas Gerais, cortaria o Espírito Santo e a Bahia), ressaltando as vantagens e a necessidade de seu desenvolvimento para bem do comércio e navegação ANRJ, Ministério do Brasil, Reino e Estrangeiros, Correspondências com Províncias, cx 5F-65 (GIFI). Esta Correspondência não está datada, mas foi enviada entre os anos de 1808-1812, englobados pela caixa na qual se localiza.
} 
das rotas de peregrinações, resultou em disputas e oposições também entre as diversas partes do continente do Brasil. ${ }^{68}$

Portanto, apesar de vislumbrarem e encamparem o projeto de regeneração do Império a partir de sua nova sede, proprietários e comerciantes incrustados nas diferentes partes do "mosaico" que constituía a América - ainda portuguesa - não o faziam embasados em interesses recíprocos, ou em sentimentos identitários de forte poder coesivo, capazes de dar solidez ao corpo político imaginado. Pensavam, sim, em vínculos diretamente estabelecidos com o novo centro político-econômico imperial, ou com a própria Lisboa - caso de algumas capitanias setentrionais, como a do Grão-Pará ${ }^{69}$-, nas vantagens particulares que a partir destes poderiam auferir, expressando um "patriotismo imperial" irredutível a um suposto nacionalismo emergente.

Neste sentido, acreditamos, as "políticas pragmáticas" levadas a cabo pelo reinado joanino visando fixar as bases da Monarquia na nova sede do Império incluindo a expansão do comércio e atividades produtivas; medidas protecionistas; abertura de estradas e caminhos inter-regionais, bem como projetos de "infraestrutura" e uma "liberal política de distribuição de terras" - não surtiram o efeito de uniformizar as diversas partes da colônia e, tampouco, de Minas Gerais.

Ao contrário, Minas oitocentista revelou-se muito mais economicamente diversificada e regionalmente diferenciada, contando com um perfil econômicodemográfico dinâmico e variado, estabelecendo uma hierarquia entre espaços sociais que anteriormente se relacionavam de forma horizontal, bem como

\footnotetext{
${ }^{68}$ Assim, numa correspondência enviada pela Câmara de Natal, em 30 de abril de 1808, o autor buscava associar o desenvolvimento da sua Capitania ao do Império - visto ser ela "parte integrante do Rico Brasil" - ainda que tal desenvolvimento ocorresse à expensas dos interesses da Capitania de Pernambuco, à qual a do Rio Grande do Norte estaria sujeita, pela necessidade de pagar, "em todos os gêneros de Comércio vindo ou indo desta Capitania para a Metrópole Nacional (...) "dois fretes e suas comissões, enquanto os Pernambucanos pagam só um (...)”. (ANRJ, Negócios de Portugal, MR, cx 5F-516 (GIFI)).

${ }^{69}$ MACHADO, André Roberto de A. A quebra da mola real das sociedades. A crise política do Antigo Regime português na Província do Grão-Pará (1821-1825). São Paulo: USP/FFLCH, 2006. (Tese de doutoramento).

${ }^{70}$ Nos termos sugeridos por Guerra, para o caso da América espanhola, o que se observou desde então fora um verdadeiro surto de "patriotismo imperial", o qual, seguramente, resguardou especificidades bem nítidas para o caso da colônia portuguesa. (GUERRA, François-Xavier. A nação na América espanhola - a questão das origens. (tradução de Marco Morel). In: Revista Maracanan, Rio de Janeiro: UERJ, n. 1, 1999/2000, p. 9-30.

${ }^{71}$ LENHARO, Alcir. As tropas da Moderação. O abastecimento da Corte na formação política do Brasil: 1808-1842). 2a . Ed. Rio de Janeiro: Secretaria Municipal de Cultura, Turismo e Esportes/ Departamento Geral de Documentação e Informação Cultural, Divisão de Editoração, 1993, p. 27.
} 
aprofundando o processo de reordenamento dos pólos de poder ${ }^{72}$. Tudo isso, inscrevendo as construções identitárias na múltipla e simultânea convivência de diversos níveis de pertencimento político e de novos valores e referenciais, desde então veiculados.

$*$

Dentre as medidas concretas que atuaram neste sentido, nenhuma suscitou maiores expectativas que o Alvará de $1^{\circ}$. de abril de 1808 , liberalizando a instalação de fábricas e manufaturas no Brasil ${ }^{73}$, pois, conforme crença que permeou o governo de D. Francisco de Assis Mascarenhas - o Conde de Palma (1810 a 1814) - e boa parte do seguinte - exercido por D. Manoel de Portugal e Castro (1814-1821) -, "nenhuma outra Capitania" contava com tão propícias circunstâncias: "nós temos o algodão em abundância e da melhor qualidade; temos já o linho, e poderemos ter também as lãs. Novas e bem dirigidas fábricas, darão valor às matérias primeiras, os lavradores aumentarão suas plantações, a indústria promoverá a agricultura e ambas o Comércio e a opulência do País". ${ }^{74}$

Além dos efeitos dinâmicos que a indústria promoveria sobre o comércio e a agricultura da Capitania, vislumbrou-se com especial ênfase as possibilidades de reversão da decadência mineradora, cujos principais entraves eram imputados à falta de infra-estrutura e, principalmente, aos altos preços do ferro e aço. Desse modo, uma série de fábricas de ferro foi ensaiada nas Comarcas de Ouro Preto, Sabará e Serro ${ }^{75}$. Empreendimentos vislumbrados como "índices de progresso", correspondentes aos ideais de "civilidade" e "espírito público", adquiridos por meio do trabalho produtivo. ${ }^{76}$

\footnotetext{
${ }^{72}$ PAIVA, Clotilde Andrade. População e Economia nas Minas Gerais do Século XIX, op. cit.

${ }^{73}$ CHAMON, Carla Simone, op. cit.

74 “Correspondência do Exmo Sr. D. Francisco de Assis Mascarenhas, para a Real Junta do Comércio", 30 de julho de 1813, in: RAPM, Ano XIX, 1921, p. 245.

75 “Correspondência de D. Francisco de Assis Mascarenhas", in: RAPM, Ano XX, 1924, p. 372, 373, 381 e 384. A primeira de iniciativa da Coroa foi a Fábrica de Ferro do Morro do Pilar, autorizada a 10 de outubro de 1808 e instalada ao sul do arraial do Tejuco, sob orientação do Intendente Câmara. Além dessa, mereceu destaque a Fábrica de Ferro de Congonhas - "a primeira que produziu ferro, e começou a trabalhar com alguma regularidade", segundo o Conde de Palma - bem como o estímulo à produção das minas "da Galena do Abaeté, do Paraopeba" e a abertura de "novos e mais fáceis caminhos para a extração do estanho" e do "salitre", sob supervisão do Barão d'Eschwege.

${ }^{76}$ CHAMON, Carla Simone, op. cit., p. 74-76.
} 
A associação não era inédita - informando as reflexões de Saavedra sobre as causas de uma "tão extraordinária moléstia pública"77 - mas, a partir de 1808, ela ganha concretude, implicando a mobilização de vários segmentos da sociedade mineira em torno de suas viabilizações. É assim que se explica o entusiasmo dos diversos acionistas que concorriam para a formação de sociedades destinadas a levantar os fundos necessários para a criação de Fábricas - caso da nova Fábrica de Ferro de Congonhas ${ }^{78}$-, bem como o espírito empreendedor de particulares, a exemplo do morador do Tejuco, Bento Dias Chaves, que construíra em sua fazenda em Sabará "um engenho de cardagem de algodão, e um filatório", notícia que animava o Conde de Palma a ver erigida "nesta Capitania, ainda que em ponto pequeno, uma Fábrica de Algodões semelhante àquelas, que tão vantajosamente se haviam estabelecido em Portugal"79.

A nosso ver, além da expectativa do lucro e dos "privilégios" - vistos como "indispensáveis a todo estabelecimento" 80 -, tais iniciativas foram movidas pelo desejo de ingresso numa nova época de prosperidade, capaz de fazer da Capitania mineira uma das "mais interessantes dos Estados do Brasil" $"$. Simultaneamente, autoridades da capitania desviavam as atenções do tradicionalmente diagnosticado problema dos extravios e contrabandos - como causa da "diminuição das Rendas Reais" e do "desfalque e decadência atual" da Capitania ${ }^{82}$ - para o que entendiam como as verdadeiras causas da diminuição da arrecadação, imputadas à "falta de braços" - já que os filhos dos mesmos mineiros "de ordinário

\footnotetext{
${ }^{77}$ SAAVEDRA, Basílio Teixeira de, op. cit.

78 "Correspondência do Conde de Palma ao Conde de Aguiar", de 30 de junho de 1813, in: RAPM, Ano XIX, op. cit., p. 234-235.

79 “Correspondência do Conde de Palma com a Secretaria de Estado dos Negócios do Brasil”, de 9 de novembro de 1813, in: RAPM, Ano XX, op. cit., p. 373.

80 "Correspondência do Conde de Palma ao Conde de Aguiar", de 30 de junho de 1813, in: RAPM, Ano XIX, op. cit., p. 234-235.

81 "Correspondência do Conde de Palma com a Secretaria de Estado dos Negócios do Brasil", de 20 de agosto de 1813, in: RAPM, Ano XIX, op. cit., p. 257-259.

82 "Memória ou Plano de Jacinto Alves da Silva", sobre o qual deu parecer D. Manuel de Portugal e Castro, em 5 de janeiro de 1818. ANRJ, IJJ9, cód. 469, cx 392, doc 6; "Correspondência do Conde de Palma com o Ministério dos Negócios da Guerra", em 19 de setembro de 1813, in: RAPM, Ano XX, op. cit., p. 356-357; "Parecer de D. Manuel de Portugal e Castro sobre o Plano de Jacinto Alves da Silva", in: ANRJ, IJJ9, cód. 469, cx 392, doc 6.
} 
seguem outro ramo de vida" 83 - e de "meios", necessários a se extrair o ouro "hoje muito dificultoso em algumas terras" 84 .

Cabe ainda notar que a esperança na reversão da decadência através dos empreendimentos produtivos assumia nova dimensão, pois os limites das autonomias conquistadas deixavam de estar dados pela condição colonial. Se num primeiro momento estes diagnósticos desautorizavam toda e qualquer medida restritiva das autonomias conquistadas - dentre as quais as "interessantíssimas" comunicações intra e intercapitanias - paulatinamente, os benefícios conquistados convertiam-se em moeda de troca da rendição da obediência e fidelidade ao Soberano, em nome da qual as elites mineiras rogavam pela "conservação e prosperidade de todos os seus Reinos e Domínios nas quatro partes do Mundo" ${ }^{86}$

Seguramente, os benefícios auferidos com a vinda da Corte não implicaram a conquista da soberania do Brasil. Entretanto, para além do caráter irreversível que estes assumem - sendo condição indispensável no forjamento das bases sociais do Estado - há que se considerar o fato incontestável segundo o qual, ao alterar o equilíbrio entre as diferentes partes do conjunto articulado em torno da Monarquia, aprofundando as assimetrias historicamente construídas, 1808 representou um marco fundamental na erosão do poder coesivo desta dimensão macropolítica, organizadora da diversidade. Isto por que, desde então, as muitas pátrias que lhe davam materialidade, ajustando-se de modo diferente ao desdobrar-se da crise passaram, reversivamente, a exigir ajustes cada vez mais profundos na organização do conjunto, impondo à Monarquia o equacionamento de demandas múltiplas e por vezes irreconciliáveis.

\footnotetext{
83 "Correspondência do Conde de Palma com o Ministério dos Negócios da Guerra", em 19 de setembro de 1813 , op. cit., p. 356. Por "outro ramo de vida" o governador seguramente se referia às atividades alternativas que brotaram com a própria mineração e tomaram vulto após a crise desta, conforme discutido no capítulo anterior.

84 "Parecer de D. Manuel de Portugal e Castro sobre o Plano de Jacinto Alves da Silva", in: ANRJ, IJJ9, cód. 469, cx 392, doc 6.

85 “Ofício de D.Manuel de Portugal e Castro em que fala da matéria da diminuição progressiva do Rendimento do Real quinto a par da continuada e escandalosa falsificação de moeda nesta Capitania", 1815, ANRJ, IJJ9, cód. 469, cx 392, doc 10.

86 "Ofício da Vila da Campanha da Princesa", de 15 de janeiro de 1814, in: ANRJ, Fundo IJJ9, pac. 525, cx 504 .
} 
No plano do simbólico, o significado das identidades construídas a partir das muitas pátrias acompanhou a "complexificação" do processo apontado, no qual a elevação do Brasil à condição de Reino Unido merece destaque, à medida que pode ser tomado como o primeiro modelo político de ordenamento da diversidade em resposta às novas condições criadas pela crise. ${ }^{87}$

Entre proprietários e administradores das diferentes partes do reino do Brasil, tal medida ecoou como a instalação de uma completa "igualdade” em relação aos súditos peninsulares, reforçando, momentaneamente, a adesão ao referencial de pertencimento político mais geral: a grande família de "Portugueses de ambos os hemisférios" $"$. Edificada sob uma mesma identidade lusitana, a propagada "união" era então associada ao próprio fim da "indiscreta rivalidade, que ainda se deixava perceber nas classes ignorantes do povo, entre Portugueses Americanos e Portugueses Europeus" ${ }^{~} 89$. Entretanto, ela também era edificada sobre condições supostamente naturais, já que decorrência da própria "extensão, grandeza e produtos deste fertilíssimo continente", que "reuniu todos os Portugueses, como Irmãos, e Membros de uma só Família, debaixo das vistas e dos cuidados de seu Pai comum"90.

Neste sentido, unindo pelos "sentimentos e afetos" povos tão distantes, a nova categoria política teria representado o fundamento necessário do projeto para se criar um "vasto Império nestas serenas Regiões do Novo Mundo" confirmando, definitivamente, a inversão do princípio da reciprocidade de interesses entre as partes. A partir de agora, argumentava-se, quando a "Presença Soberana (...) trabalha tão eficazmente na nossa Regeneração, trabalha ao mesmo tempo

\footnotetext{
${ }^{87}$ JANCSÓ, István \& PIMENTA, João Paulo Garrido. Peças de um mosaico, op. cit.

${ }^{88}$ Numa Memória sobre a Capitania de Santa Catarina, escrita no Rio de Janeiro no ano de 1816, por Paulo José Miguel de Brito, registra-se a seguinte impressão sobre a nova categoria política do Brasil: "Mas o Régio e Benigno Coração não estava ainda satisfeito com tantos benefícios; faltava-lhe igualar ainda em tudo os habitantes deste precioso país com os de Portugal; e para isto elevou o Brasil à categoria de Reino, e o uniu àquele politicamente, para também unir civilmente e identificar em uma só família os Portugueses de ambos os hemisférios". (BRITO, Paulo José Miguel de, Memória Politica sobre a Capitania de Santa Catarina, em 1816... ”, BNRJ, Seção de Obras Raras, 76,1,12). ${ }^{89}$ Idem.

${ }^{90}$ Sermão de Ação de Graças que no dia 13 de maio celebrou o senado da Câmara desta Capital do Pará, pela Feliz Aclamação do Muito Alto e Poderoso Senhor D. João 6 ${ }^{\circ}$., Rei do Reino Unido de Portugal, do Algarves e do Brasil, recitado e oferecido a S. M. Fidelíssima pelo Presbítero Romualdo Antonio de Seixas, professo da Ordem de Cristo e Cônego da Catedral da mesma cidade. Pará, 12 de junho de 1817. (ANRJ, MR, cx 646, vol. 1, ref. 012816).
} 
na vossa [de Portugal], pela recíproca influência dos seus benefícios nos três Reinos (...)". ${ }^{91}$

A mesma tônica povoava o discurso dos estadistas joaninos, representando, na interpretação de José da Silva Lisboa - funcionário imperial e à época transitando de suas reflexões econômicas para as de natureza política ${ }^{92}-\mathrm{a}$ correção de supostas "anomalias, que antes por extremo desigualavam a sorte dos filhos a respeito dos pais nascidos na Metrópole", instaurando o próprio "Espirito de Nacionalidade" ${ }^{93}$. Nas reflexões de Silvestre Pinheiro Ferreira - que profundamente refletiu sobre as novas circunstâncias instauradas - reconheciase que a declaração de 1815 era a simples expressão formal "de um fato, aliás incontestável; a saber: Que o Brasil era chegado à Altura de civilização precisa para se governar, reunido a Portugal, como este Reino, por Leis e Magistrados", e que, portanto, "entenderam logo seus Habitantes que este Reino não podia deixar de ter uma Capital dentro em si mesmo." 94

Observa-se, desse modo, que a nova categoria política da ex-colônia, ao mesmo tempo em que abrigava a idéia da instituição de uma "completa igualdade" entre os habitantes dos dois hemisférios, reforçando a adesão à identidade lusitana, redimensionava-a segundo um novo referencial político que, dotado de "precisa territorialidade" - o Reino do Brasil - e de um "centro de gravidade" de todo o Império, dava tangibilidade ao corpo político imaginado ${ }^{95}$, cujo fundamento simbólico - a natural superioridade americana - abrigava as condições para a formatação de uma identidade especificamente brasileira. ${ }^{96}$

Estas transformações operadas no plano do Estado e dos próprios fundamentos simbólicos da Monarquia - a partir das quais se gestaram as condições concretas para a Independência - aprofundaram-se mediante os acontecimentos

\footnotetext{
${ }^{91}$ Idem.

${ }_{92}^{92}$ PAIM, Antônio. Cairú e o Liberalismo Econômico. Rio de Janeiro: GB, 1968, p. 31.

${ }^{93}$ LISBOA, José da Silva. Memória dos Beneficios Politicos do Governo de El-Rei Nosso Senhor D. João VI. Rio de Janeiro: Imprensa Régia, 1818, p. 111- 117.

94 "Informação verbal do Ministro dos Negócios Estrangeiros no ato da Conferência de 15 de março de 1822 da Comissão de Cortes sobre os Negócios do Brasil”. (ANRJ, Documentos sobre a Independência, caixa 740, doc 4, 22 de março de 1822).

${ }^{95}$ JANCSÓ, István \& PIMENTA, João Paulo Garrido. Peças de um Mosaico, op. cit., p. 127-176.

${ }^{96}$ Segundo Xavier Guerra, o "reino remete, na verdade, a uma unidade política completa, englobando múltiplas comunidades locais num território dotado das mesmas instituições e de um mesmo governo", implicando, ainda, "uma unidade moral pelo sentimento que seus habitantes têm de uma filiação e de uma diferença comuns com comunidades análogas". (GUERRA, François-Xavier. A nação na América espanhola: a questão das origens, op. cit., p. 15).
} 
revolucionários detonados em 1817 os quais, tanto em Portugal, quanto em Pernambuco, esgarçaram alterações qualitativas nos fundamentos da "moldura". Repercutindo profundamente nas percepções e atitudes dos estadistas e grupos políticos locais situados em diferentes partes do Brasil, punha-se em relevo, desde então, a definição de um assento definitivo para a Monarquia, bem como a questão dos princípios garantidores de sua legitimidade, visivelmente abalados. E aqui, é na esteira da contra-revolução que se pode dimensionar a eficácia da simbologia envolvida na aclamação de D. João VI na América, em 6 de fevereiro de 1818.

Seguramente, a mobilização produzida nas celebrações festivas reprisadas em diversas Vilas apelava para representações tradicionais da figura real, suscitando expectativas positivas especialmente emitidas pelas Capitanias do CentroSul, cimentando o sentimento de naturalização da Monarquia, representando, enfim, ocasião em que os "inumeráveis Povos de todas as Classes" reafirmavam os laços de "fidelidade" e "vassalagem" à pessoa real e, unidos pelos sentimentos de "amor", "zelo" e "respeito", reavivavam um cerimonial de ritos seculares ${ }^{97}$.

É assim que podemos avaliar a simbologia envolvida nos festejos ocorridos em Sabará, por ocasião da aclamação de D. João VI, ocasião em que uma embaixada africana desfilava "um Carro todo coberto de Damasco em forma de Embarcação", que entrara na praça trazendo uma bandeira no topo com a legenda: "Na Aclamação do Rei dos Lusitanos, também o gosto chega aos Africanos". Dele, "saíram Figuras africanas vestidas com muita riqueza, e propriedade tocando instrumentos do seu País e dançando em companhia do seu Maioral o qual rendendo Vassalagem ao senhor Dom João Sexto, Cujo Retrato apareceu no mesmo Carro debaixo de um rico Docel, lhes fez a seguinte fala:

Amados Companheiros, que viestes das remotas Praias Africanas, só para contemplar e render Vassalagem ao Melhor dos Reis, aquele (...) que Veio Fundar na América um Novo Império; vinde ali $\mathrm{O}$ tendes, chegai sem susto, e prostrai-vos aos Reais Pés do Nosso Benfeitor, do Nosso Pai, e enfim do Nosso Augustíssimo Senhor, e Monarca O Grande João Sexto Fundador deste Vasto Reino do Brasil; dedicai-lhe pois os devidos cultos, em nome dos imensos Povos, que habitam a Adusta África nossa Pátria (...); eia, Amigos e Companheiros, uni os vossos sinceros votos

\footnotetext{
${ }^{97}$ Ver aqui as correspondências das Câmaras para os anos em questão, publicadas em As Câmaras Municipais e a Independência. Rio de Janeiro: Arquivo Nacional, 1973, vols. 1 e 2.
} 
aos destes ditosos Brasileiros (...). ${ }^{98}$

O envio de uma embaixada africana ao Brasil, na ocasião de tão importante festividade pública, não era fato inédito nas práticas políticas que articulavam as diferentes partes da Monarquia portuguesa, no século XVIII ${ }^{99}$. Tampouco a rendição de vassalagem à figura real era desprovida de sentido para os africanos, em cujas sociedades - especialmente entre os da África Central, maioria étnica em diversas regiões das Minas -, representava o símbolo mais visível, por referência ao qual se constituíam as identidades coletivas e o povo reconhecia-se como "comunidade solidária". ${ }^{100}$

De qualquer forma, convivendo com estas referências múltiplas, catalisadas pela mistura do extraordinário e do exótico, constituindo "tópicas bem marcadas" pertencentes a um modo de fazer política característico do Antigo Regime, as expressões grifadas corroboram o argumento segundo o qual, a partir de 1815 - e mais fortemente 1818 -, em paralelo à vigência da identidade portuguesa, os habitantes do mosaico americano passavam a perceber-se, também, como constitutivos de um "bloco" - americano/brasileiro - contraposto a outro - o reinol -, pelo que, não só Portugal perdia definitivamente o estatuto de centro catalisador das rotas de peregrinação que articulavam as diferentes partes do Império, como a "identidade nacional portuguesa perdia em coesão interna, anunciando, pela negativa, a configuração da relação de alteridade", politizada no contexto da independência. ${ }^{101}$

\footnotetext{
98 "Festejos em Sabará na ocasião da aclamação de D. João VI (1817)", in: RAPM, ano X, fasc. III e IV, jul-dez de 1805, p. 735-740. (grifo meu)

${ }^{99}$ Segundo Silvia Lara, talvez as mais antigas de que se tenha notícia sejam as enviadas pelo rei do Congo e seus aliados a Nassau, em 1642. As mais conhecidas são aquelas mandadas pelos reis da costa ocidental da África, a partir de meados do século XVIII, com claros interesses comerciais. Elas ocorreram entre 1750 e 1811, no contexto da expansão daomeana e das complexas relações entre Portugal, a Bahia e os reinos da Costa da Mina: foram quatro embaixadas enviadas aos portugueses pelo rei do Daomé, duas pelo rei de Onim (atual Lagos) e uma pelo rei de Ardra (atual Porto Novo). (LARA, Silvia H., "Reminiscências setecentistas", op. cit., p. 198 e segs.).

${ }^{100}$ Nesta acepção, talvez fosse este o sentido emprestado à aclamação de D. João VI, provavelmente associado à figura do rei como "herói-fundador", necessário para impor uma "ordem que organizasse o mundo e controlasse as forças desagregadoras". (SOUZA, Marina de Mello e. Reis Negros no Brasil Escravocrata: história da festa de coroação de Rei Congo. Belo Horizonte: Editora da UFMG, 2002, p. 27).

${ }^{101}$ JANCSÓ, István \& PIMENTA, João Paulo Garrido, op. cit.
} 


\section{De "portugueses" a "brasileiros": a inversão da lógica das alteridades}

A conjuntura de 1822 a 1831 apresenta-se sob a marca das diferentes questões externadas na trajetória "de um Império a outro", processo do qual emergiria, em meados do XIX, uma nação brasileira dotada de feição própria. Neste contexto, a opção alinhavada em torno da Monarquia Constitucional, tendo à frente um herdeiro da Casa de Bragança, revelou-se o caminho tranqüilizador que garantia alguns dogmas há muito consolidados entre elites políticas cada vez mais empenhadas na manutenção de seus interesses, muitos dos quais criados ou reforçados a partir de 1808. Desde então, esgotavam-se as condições - simbólicas e concretas - para a viabilização de uma "experiência histórica centrada em conceitos como restauração e regeneração" 102 , impondo-se, como bem notou José Bonifácio do seu leito de morte, "criar então, como por milagre, uma Nação nova, grande e respeitável" 103 .

Ao mesmo tempo, o novo modelo "mitigava a mudança radical operada nos fundamentos simbólicos" deste que constituíra o verdadeiro conceito fundante do Estado brasileiro: "a passagem de uma noção de Monarquia como dimensão macropolítica organizadora da diversidade, para aquela que a reconhecia por referência à própria Nação". ${ }^{104}$

O clima político em Minas Gerais no pós-independência descortinava estas alterações qualitativas nos "fundamentos da moldura", permitindo-nos perceber as tensões e conflitos que permearam a lenta supressão do "filtro português". Tal dinâmica traduz-se na re-significação do adesismo à persona de D. Pedro pelos grupos políticos mineiros, na conjuntura do Primeiro Reinado ${ }^{105}$. Nestes

\footnotetext{
${ }^{102}$ ARAÚJO, Valdei Lopes, op. cit.

103 “Carta de João Claro [pseudônimo utilizado por José Bonifácio] a seo Compadre Braz Escuro", in: O Tamoyo, n. 21, 9 de outubro de 1823. (O Tamoyo, 1823. Rio de Janeiro: Zélio Valverde (Ed. Fac-similar de jornais antigos), 1944, p. 85-88).

${ }^{104}$ Hipótese consolidada a partir da empiria dos trabalhos desenvolvidos no âmbito do projeto temático "Brasil: fundação do Estado e da Nação (1750-1850)", sob coordenação de István Jancsó, IEB/USP.

${ }^{105}$ Sobre a adesão a D. Pedro e o traço contratualista que esta encerra, ver: SOUZA, Iara Lis Carvalho. Pátria Coroada. O Brasil como corpo político Autônomo. 1780-1831. São Paulo: Editora da Unesp, 1999, p. 143-169). Alertamos, porém, para a evidência de que, além das clivagens impostas pela diversidade étnica e social reinante na capitania mineira, a adesão nem sempre fora a clave sobre a qual se processou a ruptura luso-brasileira. Assim, durante a própria viagem de D. Pedro a Minas, entre março e abril de 1822, evidenciaram-se não apenas práticas reveladoras do sentido de negociação assumido pela construção da unidade, que atendiam às próprias expectativas e reivindicações das diversas Vilas, como variaram profundamente os termos do novo pacto estabelecido. Estes, se ora remetiam ao reconhecimento de D. Pedro como "Digno Sustentáculo do
} 
termos, vale notar que, à época da independência, a tendência liberal-moderada da província difundia a idéia de que só "Ele podia sustentar inabalável, só Ele podia conservar o Brasil no meio de tantos balanços, que agitaram as suas Províncias", abrindo "a primeira época da glória do Brasil ${ }^{106}$.

Daí a indissociabilidade entre o divulgado patriotismo e a figura de $D$. Pedro I que, regendo-nos constitucionalmente, seria capaz de afastar tanto os "Monstros do Servilismo", quanto as "Democracias populares", por serem estas "incompatíveis com o estado da civilização moderna"107. Dando início à sua pedagogia política, a elite liberal mineira definia por "Pátria" não aquela "terra ou província em que nascemos" - compreensão comum à época, embora não única ${ }^{108}$-, mas "aquele todo que abrange o comum da grande família nacional Brasileira, e o seu Monarca"109, buscando criar o sentimento inexistente de identificação entre as várias partes do Brasil, apregoando o "amor da pátria", ou seja, deste "todo coletivamente olhado", como o "guia do nosso comportamento". "O contrário", argumentava-se, "bem longe de ser virtude, é o maior dos crimes sociais; porque se pudesse admitir a subdivisão em tal sentimento, bem depressa teríamos como virtude o abominável egoísmo, visto que por tal modo iria gradualmente descendo de Nação a província, de província a cidade, de cidade a família, e de família a indivíduo". ${ }^{110}$

Ao final do Primeiro Reinado, contudo, diversos são os indícios de que os fundamentos deste projeto de Estado dinástico estavam em transformação. Ilustrativas do sentido desta última eram as reflexões contidas num artigo do

\footnotetext{
Sistema Constitucional" - noção esta em grande medida imposta pela sociedade civil ao Príncipe, na firmação do novo pacto político -, ora esgarçava o apego à tradição dinástica, ao costume e a uma concepção do poder própria ao Antigo Regime. Sem contar, ainda, os ensaios de "autonomismo em outro nível" revelador, principalmente naquelas Vilas mais distantes da Capital mineira e do circuito Rio-Minas, do quanto o processo em curso fora suscetível aos ânimos de indivíduos que passaram ao largo da adesão quer às Cortes, quer ao governo do Rio de Janeiro. Sobre este diversificado processo, ver: SILVA, Ana Rosa Cloclet da. Identidades políticas e a emergência do novo Estado nacional: o caso mineiro. In: JANCSÓ, István (org.). Independência: História e Historiografia. São Paulo: Hucitec, 2005, p. 515-556).

${ }^{106}$ O Universal, n. 29, 21 de setembro de 1825.

${ }^{107}$ Idem.

${ }^{108}$ Recorrendo aos dicionários de época, Morel afirma ser uma constante entre o século XVIII e o XIX o emprego polissêmico da palavra "pátria", embora esta tenha sempre sido atravessada pela dicotomia local/geral. (MOREL, Marco. As transformações dos Espaços públicos. Imprensa, Atores Politicos e Sociabilidades na Cidade Imperial (1820-1840). São Paulo: Hucitec, 2005).

${ }^{109}$ O Universal, n. 29, 21 de setembro de1825.

${ }^{110}$ O Universal, n. 29, 21 de setembro de1825.
} 
Universal acerca da "influência do despotismo sobre os costumes", no qual a identificação entre a "Nação e a Pátria do Príncipe" era tida como própria a "homens corrompidos", a governos que "pouco se importam com os costumes de seus escravos e só querem sua condescendência, baixeza, e submissão ilimitada às suas vontades". ${ }^{111}$

Em vários outros números, reiterava-se a idéia de que a "única âncora do Monarca" era a Constituição - sem a qual "nem a Nação teria as sólidas garantias de que goza, nem o Monarca uma égide segura contra as tramas de qualquer partido" 112 - e de que D. Pedro fora aclamado Imperador pela Constituição, e "não por ser Herdeiro do Trono Português"113. É naquele "Contrato", portanto, que residiria o fundamento da sua "legitimidade (...) hoje, e a de todos os seus Descendentes", de modo que, enquanto ele cumpre as condições do mesmo contrato, enquanto a Nação julga que ele deve subsistir, não há direito de reação". Caso contrário, sinalizava-se com o exemplo da França, regozijando-se pela queda de Carlos X, sintonizada com a derrota do miguelismo em Portugal ${ }^{114}$, acontecimentos apresentados como um alerta aos "Tiranos" para que venham "a conhecer agora o triunfo dos povos".

A nosso ver, estes indícios corroboram o argumento de que, naquele momento, a própria Monarquia estava sendo re-inventada, num processo que acompanhou a lenta obliteração da identidade portuguesa, em nome de novos referenciais de tipo nacional. Invocando o discurso proferido no Conselho Geral da Província, em 29 de janeiro de 1831, a propósito do estabelecimento de sociedades estrangeiras na província, tratava-se do reconhecimento de que "finalmente era preciso começar, desde já, a abrasileirarmo-nos, visto que estrangeiros temos sido a mais de três séculos" ${ }^{115}$. O dilema, contudo, consistia em absorver a modernidade, sem abalar os fundamentos de uma organicidade societária tradicionalmente hierarquizada que, até recentemente, remetia à Monarquia portuguesa.

*

A questão era polêmica, pois envolvia a inflexão fundamental marcada pela independência: desde então, a identidade portuguesa passava a ser um elemento

\footnotetext{
${ }^{111}$ O Universal, n. $446,28 / 05 / 1830$.

${ }^{112}$ O Universal, n. $505,13 / 10 / 1830$.

${ }^{113}$ O Universal, n. 428, 16/04/1830.

${ }^{114}$ O Universal, n. 521, 19/11/1830 - Festejo em Baependy pela queda do trono em Portugal em sintonia com a queda de Carlos $\mathrm{X}$ na França.

${ }^{115}$ Publicado no $O$ Universal, n. 552, 2 de fevereiro de 1831.
} 
de alteridade, associado ao próprio despotismo, com o qual se desejava romper. Contudo, mediante seus "contornos ainda pouco definidos neste sentido"116, impunha-se delimitar os critérios a partir dos quais "portugueses" passariam a ter estatuto de "brasileiros".

Se no âmbito da representação nacional a diferença entre ambas as condições fora marcada pelo critério de aceitação do "novo Pacto Social" - não sem haver polêmicas neste sentido -, os conflitos que, desde então, irromperam pelas diversas províncias, opondo "portugueses" e "brasileiros", denunciavam a complexidade do quadro instalado, movido não por antagonismos circunstanciais, mas por sentimentos e interesses múltiplos enraizados durante a colonização e sua crise, impossíveis de serem harmonizados pela determinação sacramentada no projeto de Constituição: aquela que considerava cidadãos brasileiros "todos os portugueses domiciliados no Brasil antes de 12 de outubro, que expressa ou tacitamente se houverem ligado à Sociedade Brasileira" $" 117$.

De antemão, vale notar que o "patriotismo" que começa a ser cingido no contexto da Independência, comportou um forte conteúdo "antilusitano" o qual, incontido numa perspectiva exclusivamente política, supostamente expressivo de sentimentos de nacionalidade previamente existentes ${ }^{118}$, encontrara terreno propício para aflorar na conjuntura do Primeiro Reinado, quando os acontecimentos da Independência passaram a ser rememorados "como tempos de liberal 'patriotismo", invocado "como pretexto 'histórico' para os projetos de uns e outros" $" 119$, revelando-se ainda mais agudo entre as camadas populares, articuladas nos embates contra aqueles que iam sendo identificados com o sentido comum das alteridades: o "ser português".

Na província mineira, o clima não se revelou menos tenso. Convertido em variável estruturante da formatação de uma identidade de tipo nacional, o antilusitanismo esboçara-se aí, precocemente, nas disputas por "cargos públicos" - antagonizando-se com aquilo que Felício dos Santos identificara

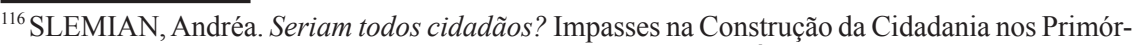
dios do Constitucionalismo no Brasil (1823-1824). In: JANCSÓ, István (org.). Independência: História e Historiografia. São Paulo: Hucitec, 2005, p. 329-349, op. cit., p. 843.

${ }^{117}$ NOGUEIRA, Octaviano (org.). Constituições Brasileiras -1824. Senado Federal; CEE/MCT, 2001, vol. 1, p. 80 .

${ }^{118}$ RIBEIRO, Gladys Sabina. A Liberdade em Construção. Identidade nacional e conflitos antilusitanos no Primeiro Reinado. Rio de Janeiro: Relume Dumará, 2002, p. 27-29.

${ }^{119}$ Idem, p. 244.
} 
como a "prepotência dos funcionários" reais, extremada em Vila Rica ${ }^{120}$-, traduzindo-se, progressivamente, num "ódio difuso aos portugueses" 121 . Este, que parece ter sido um traço peculiar da manifestação do antilusitanismo nas Minas, relativamente ao que se passava na capital do Império - onde o alvo principal do ressentimento popular foram os portugueses que dominavam o comércio a varejo e os caixeiros ${ }^{122}$ - não foi um processo contido no âmbito do enfrentamento entre as camadas dominantes, externando-se naquelas "rivalidades sempre odiosas ${ }^{123}$ " entre "Brasileiros natos, e adotivos", entre "cidadãos de diferentes nascimento e cor", capazes, aos olhos das autoridades provinciais, de promoverem "tão nocivas desordens". ${ }^{24}$

Esgarçando a inversão da lógica das alteridades pelos grupos até então identificados como "portugueses", plasmavam-se assim os contornos de uma nova consciência possível aos atores coevos: aquela que remetia ao pertencimento a uma nação que, apesar de revestida de conteúdo moderno, teorizado pelos estadistas que capitanearam tais transformações em curso em termos contratualistas, não excluía a pluralidade de substâncias que continuaram informando a compreensão dos agentes acerca do caráter "macro" assumido pelo novo modelo de organização política da sociedade.

De outro modo, as formas modernas continuaram convivendo com diferentes modalidades de organizações societárias, princípios de poder coesivos, referenciais identitários e outras tantas "nações", da mesma forma que a configuração deste incipiente nacionalismo comportou "variações relativas tanto à maneira

\footnotetext{
${ }^{120}$ SANTOS, Joaquim Felício dos. Memórias do Distrito Diamantino. 4a. Ed., Belo Horizonte: Itatiaia, 1976, p. 270.

${ }^{121}$ CARVALHO, José Murilo de. Desenvolvimiento de la Ciudadanía en Brasil. México: Fondo de Cultura Económica, 1995, p. 58.

${ }^{122}$ Os primeiros, responsabilizados pelo alto custo de vida, ao passo que os segundos apresentavamse como concorrentes dos brasileiros livres no mercado de trabalho urbano. (Ver: RIBEIRO, Gladys Sabina, op. cit., cap. 3.; ROWLAND, Roberto. Patriotismo, povo e ódio aos portugueses. In: JANCSÓ, István (org.), Brasil: Fundação do Estado e da Nação, op. cit., p. 374-376; MARTINHO, Lenira Menezes. Caixeiros e pés-descalços: conflitos e tensões em um meio urbano em desenvolvimento. in: MARTINHO, Lenira M. \& GORENSTEIN, Riva. Negociantes e caixeiros na sociedade da Independência. Rio de Janeiro: Prefeitura da Cidade do Rio de Janeiro, 1993, p. 19-124). 123 "Ofício da Câmara de Paracatú, ao Juíz Ordinário de Salgado", de 25 de junho de 1824. (APM, CMP 11, p. 61 a 62).

124 “'Ofício do Presidente da Província à Câmara de Ouro Preto, sobre partido desorganizador, tentando insuflar a rivalidade entre "brasileiros natos e adotivos", 1831. (APM, CMOP 249, p. 78 e 78v.)
} 
de conceber a relação individual ou grupal com a nação, quanto, nos termos formulados por Chiaramonte, "à relação da própria nação com outras" 125 .

Neste último sentido, as fronteiras entre o "ser brasileiro" e o "ser estrangeiro" iam além do antilusitanismo e, sem deixarem de também representar construções políticas eivadas de interesses e projetos múltiplos, esboçaram-se em Minas, fundamentalmente, na recusa à ingerência inglesa na exploração das riquezas naturais da província ${ }^{126}$. Até onde pudemos notar, adensando a expansão dos confrontantes, a recusa à ingerência inglesa era movida ainda pelo risco potencial que a afluência desses estrangeiros, portadores de grande número de escravos africanos e forros, representava para a preservação da ordem social estabelecida ${ }^{127}$.

Contudo, no tocante ao embate pela delimitação das fronteiras entre os interesses de um Império - o Brasílico - relativamente a outros em meio aos quais emergia, os referenciais invocados pelas autoridades e grupos políticos locais nem sempre coincidiram. Desprovido de sentimentos que remetessem à "proeminência da própria nação, de modo exclusivo e intolerante com relação às demais" $" 128$, o nacionalismo esboçado calcava-se em interesses ora designados como próprios a "Súditos Brasileiros", ora como caros a uma memória e a um patrimônio tidos por especificamente "mineiros" 129 , não se descartando ainda aqueles que remetiam a Vilas e localidades específicas ${ }^{130}$.

\footnotetext{
${ }^{125}$ CHIARAMONTE, José Carlos. Metamorfoses do conceito de nação durante os séculos XVII e XVIII, op. cit., p. 62 e 90.

${ }^{126}$ Sobre os empreendimentos estrangeiros nas Minas Gerais, durante a primeira metade dos oitocentos, ver: LIBBY, Douglas Cole. Transformação e trabalho em uma economia escravista. Minas Gerais no século XIX. São Paulo: Brasiliense, 1988, p. 272 e segs.

${ }^{127}$ Não raras vezes, estas tensões latentes explicitaram-se, conforme denunciado numa correspondência do juiz de paz da Vila de São José ao Presidente da província, datada de 1830, na qual informava que dois "moleques" da Companhia de Mineração Inglesa foram encontrados "armados de porretes e facas" e acabaram ferindo a um de seus auxiliares. Arrematava a correspondência indagando: "se dois moleques causam um semelhante delito o que 20 com 120 facas e outros tantos porretes, além de 40 a 50 estrangeiros que hoje existem nesta vila, podem causar?". (APM, PP 1/18, cx. 191, doc 8, ano de 1830.)

${ }^{128}$ Segundo Chiaramonte, uso este habitual do termo, na sua acepção mais conservadora, mais "de direita". (CHIARAMONTE, José Carlos. Metamorfoses do conceito de nação durante os séculos XVII e XVIII, op. cit., p. 62).

${ }^{129}$ Expressões que aparecem em polêmica veiculada pelo Universal, a propósito da ingerência inglesa nas Minas. (O Universal, n. 8, 03/08/1825, O Universal, n. 41, 19/10/1825).

${ }^{130}$ Numa "Manifestação de Júbilo pela chegada de V. M. e sua Esposa nesta Província", expedida pela Câmara de Baependi em 11 de janeiro de 1831, felicita-se pela chegada do Imperador a Minas, afirmando que "Os Brasileiros, os Mineiros, os Baependianos só querem, só sustentam, só adoram o Sistema Monárquico Hereditário Constitucional Representativo debaixo das formas tais quais juraram em 25 de março de 1824”. (ANRJ,IJJ9 759)
} 
A nosso ver, estes diversos níveis de pertencimento político que então conviveram, orientando projetos políticos alternativos aos emanados do centro, sugerem o quanto a formatação de uma identidade de tipo nacional revelou-se processo facetado pelas diferenças regionais e mesmo locais - mas também por elementos de cunho étnico, racial e social --tributário da leitura imaginária de uma coletividade cuja legitimidade precisava ser não só redescoberta ${ }^{131}$, mas, sobretudo, re-inventada.

\section{Referências bibliográficas}

ANDERSON, Benedict. Nação e consciência nacional. (Trad.), São Paulo: Ática, 1989.

ANDRADE, Marcos Ferreira de. Rebeliões escravas na Comarca de Ouro Preto. in: Vária História, Belo Horizonte, n. 17, março de 1997, p. 237-257.

ARAÚJO, Valdei Lopes de. A experiência do tempo. Modernidade e historização no Império do Brasil (1813-1845), PUC/RJ, 2003 (tese de doutoramento).

ARRUDA, Maria A. do Nascimento. Mitologia da Mineiridade. O imaginário mineiro na vida política e cultural do Brasil. São Paulo: Brasiliense, 1990, p. 182-187.

BARBOSA, Waldemar de Almeida. A Decadência das Minas e a Fuga da Mineração. Belo Horizonte: UFMG, 1971 A verdade sobre Tiradentes. Belo Horizonte: Edição do Instituto de História, Letras e Arte, s.d.

BARBOSA, Waldemar de Almeida. História de Minas. Belo Horizonte: Ed. Comunicação, 1979, vol. 3.

BERNARDES, Denis Antônio de Mendonça. O patriotismo constitucional: Pernambuco, 1820-1822. São Paulo: Hucitec, 2006.

BOXER, Carl R. A Idade de Ouro do Brasil (dores de crescimento de uma sociedade colonial). São Paulo: Cia Ed. Nacional, 1969.

CAMPOS, Milton Soares. O Papel de Minas no Brasil. In: Segundo Seminário de Estudos Mineiros. Belo Horizonte: Universidade de Minas Gerais, Segundo Seminário de Estudos Mineiros, realizado de 22 a 27 de outubro de 1956, p. 227-239.

CARVALHO, José Murilo de. (org. e intr.). Bernardo Pereira de Vasconcelos. São Paulo: Editora 34, 1999.

CARVAlHO, José Murilo de. Desenvolvimiento de la Ciudadanía en Brasil. México: Fondo de Cultura Económica, 1995.

CHAMON, Carla Simone. Festejos Imperiais: festas cívicas em Minas Gerais (1815-1845). Bragança Paulista: EDUSF, 2002.

\footnotetext{
${ }^{131}$ GIRARDET, Raoul. Mitos e Mitologias Políticas. (Trad.) São Paulo: Cia das Letras, 1987.
} 
CHIARAMONTE, José Carlos. Metamorfoses do conceito de nação durante os séculos XVII e XVIII. In: JANCSÓ, István (org.). Brasil: formação do Estado e da nação. São Paulo: Hucitec, 2003, p. 61-91.

CHIARAMONTE, José Carlos. El mito de los origenes en la historiografia latinoamericana. In: Cuadernos del Instituto Ravignani. Instituto de Historia Argentina y Americana "Dr. Emilio Ravignani”, Universidad de Buenos Aires, 3ª Série, $\mathrm{n}^{\circ} .1,1^{\circ}$. sem./1999.

COSTA, Iraci Del Nero da. Arraia-Miúda. Um Estudo sobre Não-Proprietários de Escravos no Brasil. São Paulo: MGSP Editores, 1992.

COSTA, Iraci Del Nero da. Vila Rica: População (1719-1826). São Paulo: Instituto de Pesquisas Econômicas da Faculdade de Administração da USP, 1979.

FIGUEIREDO, Luciano Raposo de Almeida. Revoltas, fiscalidade e identidade colonial na América portuguesa - Rio de Janeiro, Bahia e Minas Gerais, 16401761. São Paulo: USP/Departamento de História da Faculdade de Filosofia, Letras e Ciências Humanas, 1996. (Tese de doutoramento).

FURTADO, Júnia Ferreira (org.). Diálogos Oceânicos. Minas Gerais e as novas abordagens para uma história do Império Ultramarino Português. Belo Horizonte: Ed. UFMG, 2001.

FURTADO, Júnia Ferreira. Historiografia mineira: tendências e contrastes. in: Varia Historia, Belo Horizonte, n. 20, mar/99, p. 45-59.

GIRARDET, Raoul. Mitos e Mitologias Políticas (Trad.). São Paulo: Cia. das Letras, 1987.

GRAÇA FILHO, Afonso de Alencastro. A Princesa do Oeste e o Mito da Decadência de Minas Gerais. São João Del Rei (1831-1888). São Paulo: Annablume, 2002.

GUERRA, François-Xavier. A nação moderna: nova legitimidade e Velhas identidades. In: JANCSÓ, István (org.). Brasil: Formação do Estado e da Nação. São Paulo: Hucitec, 2003, p. 33-60.

GUERRA, François-Xavier.. A nação na América espanhola - a questão das origens. In: Revista Maracanan, Rio de Janeiro: UERJ, n . 1, 1999/2000, p. 9-30.

JANCSÓ, István \& PIMENTA, João Paulo Garrido. Peças de um mosaico (ou apontamentos para o estudo da emergência da identidade nacional brasileira. In: MOTA, Carlos Guilherme (org.), Viagem Incompleta. Formação: histórias. São Paulo: Ed. Senac, 2000, vol. 1. Hucitec/Fapesp, 2005.

(org.). Independência: História e Historiografia. São Paulo-Ijuí:

(org.). Brasil: Formação do Estado e da Nação. São Paulo: Hucitec: Ed. Unijuí; Fapesp, 2003.

\& SLEMIAN, Andréa. Um caso de patriotismo imperial. Correio Braziliense ou Armazém Literário, vol. XXX, Hypólito José da Costa. São 
Paulo: Brasília: Imprensa Oficial do Estado, 2002, Tomo I, p. 605-667.

KOSELLECK, Reinhart. Crítica e Crise (trad.). Rio de Janeiro: Eduperj/Contraponto, 1999.

LARA, Silvia Hunold. Reminiscências setecentistas. Escravidão, Cultura e Poder na América Portuguesa. Campinas: Unicamp/IFCH, 2004. (Tese apresentada para o concurso de Livre-Docência).

LATIF, Mirian de Barros. As Minas Gerais. 3ª Ed., Belo Horizonte: Itatiaia, 1991

LENHARO, Alcir. As tropas da Moderação. O abastecimento da Corte na formação política do Brasil: 1808-1842, 2a . Ed. Rio de Janeiro: Secretaria Municipal de Cultura, Turismo e Esportes/Departamento Geral de Documentação e Informação Cultural, Divisão de Editoração, 1993.

LIBBY, Douglas Cole. Transformação e trabalho em uma economia escravista. Minas Gerais no século XIX. São Paulo: Brasiliense, 1988.

LINHARES, Yedda Leite. O Brasil no Século XVIII e a Idade do Ouro: a Propósito da Problemática da Decadência. In: Seminário sobre a Cultura Mineira no Periodo Colonial. Belo Horizonte: Conselho Estadual de Cultura de Minas Gerais, 1979

LYRA, Maria de Lourdes Viana. A Utopia do poderoso Império: Portugal e Brasil: bastidores da política, 1798-1822. Rio de Janeiro: Sette Letras, 1994.

MAXWELL, Keneth. A Devassa da Devassa: a Inconfidência Mineira, Brasil Portugal, 1750-1808. 2a . Ed. Rio de Janeiro: Paz e Terra, 1978.

MELLO, Evaldo Cabral de. A fronda dos Mazombos. Nobres contra mascates. Pernambuco (1666-1715). São Paulo: Cia das Letras, 1995.

MELLO, Evaldo Cabral de. O nome e o sangue. Uma fraude genealógica no Pernambuco colonial. São Paulo: Cia das Letras, 1989.

MOREL, Marco. As transformações dos espaços públicos. Imprensa, Atores políticos e Sociabilidades na cidade Imperial (1820-1840). São Paulo: Hucitec, 2005.

NOVAIS, Fernando Antonio. Condições de privacidade na colônia. In: História da Vida privada no Brasil. São Paulo: Cia. das Letras, vol. 1, p. 13-40.

PAIVA, Clotilde Andrade. População e Economia nas Minas Gerais do Século XIX. São Paulo: USP, Depto de História, 1996. (Tese de doutoramento).

RIBEIRO, Gladys Sabina. A Liberdade em Construção. Identidade nacional e conflitos antilusitanos no Primeiro Reinado. Rio de Janeiro: Relume Dumará, 2002.

RODRIGUES, José Honório Rodrigues. História, Corpo do Tempo. Rio de Janeiro, 1976.

ROWLAND, Roberto. Patriotismo, povo e ódio aos portugueses: Notas sobre a construção da identidade nacional no Brasil independente. In: JANCSÓ, István (org.). Brasil: Formação do Estado e da Nação. São Paulo: Hucitec, 2003, p. 365-386.

RUSSEL-WOOD, A. J. R. Identidade, etnia e autoridade nas Minas Gerais do século XVIII: leituras do Códice Costa Matoso. in: Varia História, Belo Horizonte, 
n. 21, julho de 1999, p. 100-118.

RUSSEL-WOOD, A. J. R. Precondições e precipitantes do movimento de independência da América Portuguesa. In: FURTADO, Júnia F. (org.). Diálogos Oceânicos. Minas Gerais e as novas abordagens para uma história do Império Ultramarino Português. Belo Horizonte: Ed. UFMG, 2001, p. 419-463.

SANTOS, Afonso Marques dos. No Rascunho da Nação Inconfidência no Rio de Janeiro. Rio de Janeiro: Secretaria Municipal de Cultura, Turismo e Esportes, Departamento Geral de Documentação e Informação Cultural, 1992.

SILVA, Ana Rosa Cloclet da. Identidades em Construção. O processo de politização das identidades coletivas em Minas Gerais (1792-1831). São Paulo: USP/ FFLCH, 2007. (Relatório de pós-doutoramento).

SILVA, Ana Rosa Cloclet da. Inventando a Nação. Intelectuais Ilustrados e Estadistas Luso-Brasileiros na crise do Antigo Regime Português. São Paulo: Hucitec, 2006.

SILVA, Ana Rosa Cloclet da. Identidades políticas e a emergência do novo Estado nacional: o caso mineiro. In: JANCSÓ, István (org.). Independência: História e Historiografia. São Paulo-Ijuí: Hucitec/Fapesp, 2005, p. 557-576.

SILVEIRA, Marco Antonio Silveira. O Universo do Indistinto. Estado e Sociedade nas Minas Setecentistas (1735-1808). São Paulo: Hucitec, 1997.

SLEMIAN, Andréa. Sob o Império da Lei. Constituição e unidade nacional na formação do Brasil (1822-1834). São Paulo: USP/FFLCH, 2006. (Tese de doutoramento).

SLEMIAN, Andréa. Seriam todos Cidadãos? Impasses na Construção da Cidadania nos Primórdios do Constitucionalismo no Brasil (1823-1824). In: JANCSÓ, István (org.). Independência: História e Historiografia. São Paulo: Hucitec, 2005, p. 329-349.

SOUZA, Laura de Mello e. Norma e Conflito. Aspectos da História de Minas no século XVIII. Belo Horizonte: Ed. UFMG, 1999.

SOUZA, Laura de Mello e. Tensões sociais em Minas na segunda metade do século XVIII. In: Novaes, Adauto (org.), Tempo e História. São Paulo: Cia das Letras, 1992, p. 347-366.

SOUZA, Laura de Mello e. Os Desclassificados do Ouro. A pobreza mineira no século XVIII. Rio de Janeiro: Edições Graal, 1982, p. 99.

SOUZA, Marina de Mello e. Reis Negros no Brasil Escravocrata: história da festa de coroação de Rei Congo. Belo Horizonte: Editora da UFMG, 2002.

STUMPF, Roberta Giannubilo. Filhos das Minas, americanos e portugueses: identidades coletivas na Capitania das Minas Gerais (1763-1792). São Paulo: USP/Depto. de História, 2001. (Dissertação de Mestrado).

Recebido: março/2008 - Aprovado: setembro/2008 